\title{
Cancer-Testis Antigens in Triple-Negative Breast Cancer: Role and Potential Utility in Clinical Practice
}

\author{
Runyi Adeline Lam ${ }^{1}$, Tracy Zhijun Tien ${ }^{2}$, Craig Ryan Joseph ${ }^{3}$, Johnathan Xiande Lim ${ }^{4}$, Aye Aye Thike ${ }^{4}$, \\ Jabed Iqbal ${ }^{4}$, Puay Hoon Tan ${ }^{4}$ and Joe Poh Sheng Yeong ${ }^{2,4,5, * \text { (D) }}$ \\ 1 MD Programme, Duke-NUS Medical School, Singapore 169857, Singapore; e0415976@u.duke.nus.edu \\ 2 Institute of Molecular and Cell Biology (IMCB), Agency of Science, Technology and Research (A*STAR), \\ Singapore 138648, Singapore; tracytien96@gmail.com \\ 3 School of Biological Sciences, Nanyang Technological University, Singapore 637551, Singapore; \\ craig001@e.ntu.edu.sg \\ 4 Division of Pathology, Singapore General Hospital, Singapore 169608, Singapore; \\ johnathan.lim.xiande@sgh.com.sg (J.X.L.); daw.aye.aye.thike@sgh.com.sg (A.A.T.); \\ jabed.iqbal@singhealth.com.sg (J.I.); tan.puay.hoon@singhealth.com.sg (P.H.T.) \\ 5 Singapore Immunology Network (SIgN), Agency of Science, Technology and Research (A*STAR), \\ Singapore 138648, Singapore \\ * Correspondence: yeongps@imcb.a-star.edu.sg; Tel.: +65-6123-4567
}

check for

updates

Citation: Lam, R.A.; Tien, T.Z.; Joseph, C.R.; Lim, J.X.; Thike, A.A.; Iqbal, J.; Tan, P.H.; Yeong, J.P.S. Cancer-Testis Antigens in Triple-Negative Breast Cancer: Role and Potential Utility in Clinical Practice. Cancers 2021, 13, 3875. https://doi.org/10.3390/

cancers13153875

Academic Editor: Sara A. Hurvitz

Received: 17 June 2021

Accepted: 27 July 2021

Published: 31 July 2021

Publisher's Note: MDPI stays neutral with regard to jurisdictional claims in published maps and institutional affiliations.

Copyright: (c) 2021 by the authors. Licensee MDPI, Basel, Switzerland. This article is an open access article distributed under the terms and conditions of the Creative Commons Attribution (CC BY) license (https:// creativecommons.org/licenses/by/ $4.0 /)$.
Simple Summary: Triple-negative breast cancer (TNBC) has been associated with worse prognoses due to the limited treatment options. Thus, there is a need to characterise new biomarkers or treatment targets to improve patient outcomes. Cancer testis antigens (CTAs) are a group of antigens that are preferentially expressed in tumours and exhibit strong immunogenicity, as such, CTAs hold great promise as potential treatment targets and biomarkers in cancer. Previous reports have implicated roles for CTAs in different subtypes of breast cancer, including TNBC. Multiple clinical trials are in progress investigating CTAs as treatment targets in various cancers. This review aims to discuss the roles of CTAs in TNBC and discuss the potential applications and benefits of incorporating CTAs in clinical practice.

Abstract: Breast cancer cells commonly express tumour-associated antigens that can induce immune responses to eradicate the tumour. Triple-negative breast cancer (TNBC) is a form of breast cancer lacking the expression of hormone receptors and cerbB2 (HER2) and tends to be more aggressive and associated with poorer prognoses due to the limited treatment options. Characterisation of biomarkers or treatment targets is thus of great significance in revealing additional therapeutic options. Cancer-testis antigens (CTAs) are tumour-associated antigens that have garnered strong attention as potential clinical biomarkers in targeted immunotherapy due to their cancer-restricted expressions and robust immunogenicity. Previous clinical studies reported that CTAs correlated with negative hormonal status, advanced tumour behaviour and a poor prognosis in a variety of cancers. Various studies also demonstrated the oncogenic potential of CTAs in cell proliferation by inhibiting cell death and inducing metastasis. Multiple clinical trials are in progress to evaluate the role of CTAs as treatment targets in various cancers. CTAs hold great promise as potential treatment targets and biomarkers in cancer, and further research could be conducted on elucidating the mechanism of actions of CTAs in breast cancer or combination therapy with other immune modulators. In the current review, we summarise the current understandings of CTAs in TNBC, addressing the role and utility of CTAs in TNBC, as well as discussing the potential applications and advantage of incorporating CTAs in clinical practise.

Keywords: triple-negative breast cancer; cancer testis antigens; pathology 


\section{Introduction}

Breast cancer is a heterogeneous disease that can be classified based on the clinical, morphological and biological characteristics [1,2]. Triple-negative breast cancers (TNBC), a special class of breast cancers that are negative for oestrogen receptor (ER), progesterone receptor (PR) and HER2 (cerbB2), represent $9-17 \%$ of all breast carcinomas, depending on the threshold for ER, PR and HER2 positivity [1,3-5]. TNBC are also of high histological grade, displaying aggressive clinical behaviour with poorer prognosis and accompanied by frequent metastasis to the brain and lungs, with a shorter time to recurrence and death $[3,5]$.

Clinical outcomes in breast cancer based on disease-free survival (DFS) and overall survival (OS) have been enhanced over the years by incorporating different factors, such as molecular classification, as well as other clinical parameters, such as menopausal status, performance status and the stage of the disease, in treatment algorithms [5,6]. Despite the recent advances, issues such as the significant number of non-responders limit the effectiveness of personalised treatment. Results from a retrospective study involving 9156 breast cancer patients found that survival for guideline-adherent non-TNBC patients are significantly better compared to guideline-adherent TNBC patients, and the underlying reason is currently not known [7]. Thus, there is a constant need to improve the protocols and to formulate new strategies for human breast cancer management, especially for patients with limited treatment options such as those with TNBC [5]. Several studies have identified novel biomarkers and new strategies to improve the diagnosis and treatment of TNBC [3,8-17].

Cancer testis antigens (CTAs) are tumour antigens that are expressed normally in embryonic stem cells and testicular germ cells and minimally expressed in most other tissues. CTAs are aberrantly found in various cancers, especially advanced cancers with stem-cell-like characteristics $[18,19]$. CTAs were first identified in 1991 in a study showing that the presence of MAGEA1 caused resistant tumour cell clones to be sensitised to killing by autologous cytotoxic T-lymphocytes [20]. Since then, there has been an explosion of CTA-related research and the discovery of more CTAs, including NY-ESO1, which is the most successful target to date for cancer immunotherapy [21,22]. The number of CTAs identified has also increased exponentially over the years. In 2009, a database was created of about 70 families and more than 200 members of CTAs [23]. With the advent of nextgeneration sequencing, there has been a huge increase in genomic data. By integrating transcriptomic data from multiple databases, Wang et al. systematically identified 876 new CTAs in 19 cancers [24], and a different research group found an additional 201 new CTAs [25].

Various studies have found the expression of individual or sets of CTAs in tumours correlates with worsening survival, thus there has been speculation that CTAs could promote aggressive tumour growth or increase the resistance of cancer to chemotherapy [26-29]. Several studies have also described the oncogenic role of individual CTAs in human tumour cells, and the CTA functions can be divided into three categories: transcriptional regulation, mitotic accuracy, and protein turnover [29]. CTAs' cancer-restricted pattern of expression, strong immunogenicity and oncogenic roles in cancer make them attractive targets for cancer immunotherapy and the development of CTA-based vaccine treatments for patients with limited treatment options, such as those with TNBC.

In this review, we discuss the role and potential applications of CTAs in TNBC. Based on our understanding, this is the first article to comprehensively review CTAs that are expressed in TNBC.

\section{Expression of CTAs in Triple-Negative Breast Cancer}

TNBC frequently express CTAs (Figure 1), and a summary of the CTAs commonly associated with TNBC is shown in Table 1. 


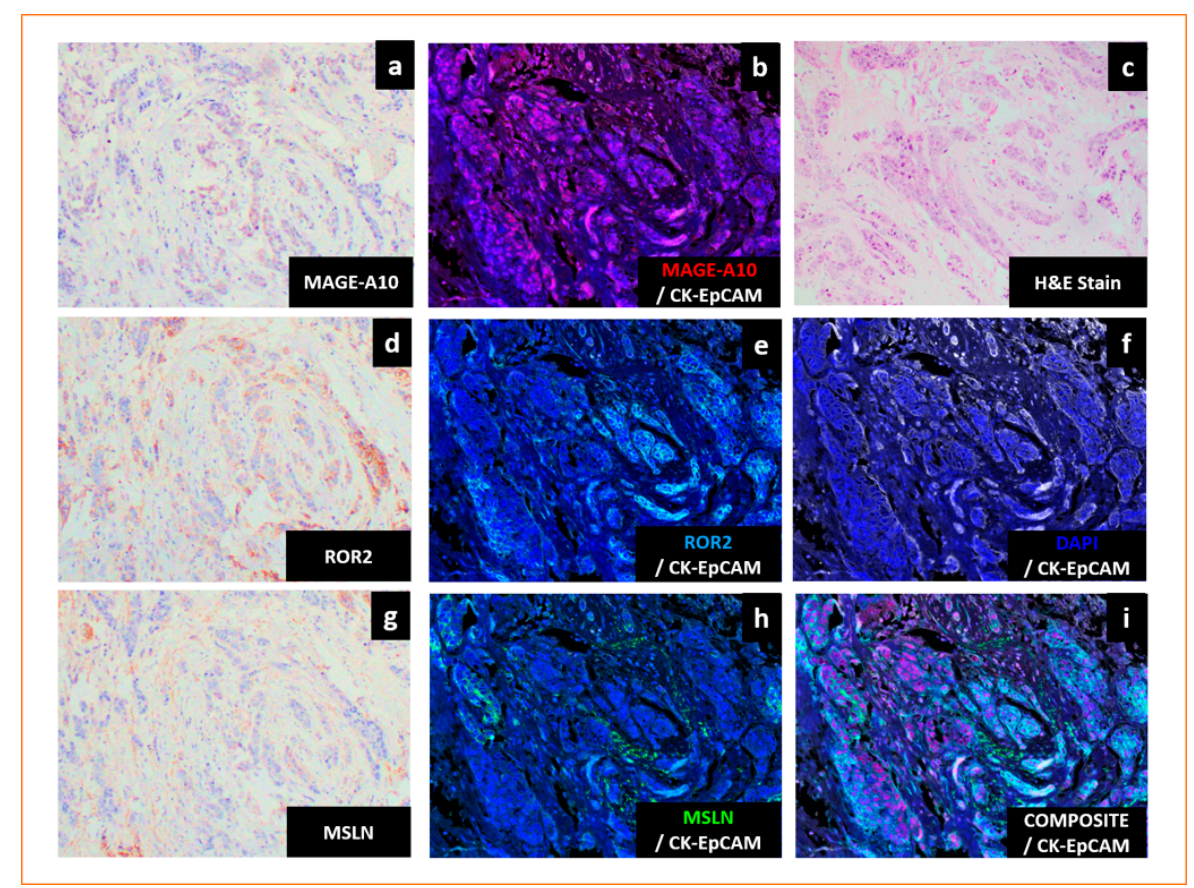

Figure 1. Cancer testis antigens are expressed in triple-negative breast cancers (TNBC). (a-i) Representative images of TNBC expressing melanoma antigen gene-A10 (MAGE-A10), receptor tyrosine kinase-like orphan receptor 2 (ROR2) and mesothelin (MSLN). (a) Immunohistochemistry (IHC) nuclear staining of MAGE-A10 (brown). (b) Multiplex IHC (mIHC) labelling of MAGE-A10 (red), cytokeratin- epithelial cell adhesion molecule (CK-EpCAM) (white) and DAPI (blue). (c) Haematoxylin and eosin (H\&E) staining. (d) IHC membrane staining of ROR2 (brown). (e) mIHC labelling of ROR2 (cyan), CK-EpCAM (white) and DAPI (blue). (f) mIHC labelling of CK-EpCAM (white) and DAPI (blue). (g) IHC membrane staining of MSLN (brown). (h) mIHC labelling of MSLN (green), CK-EpCAM (white) and DAPI (blue). (i) mIHC labelling of MSLN (green), MAGE-A10 (red), ROR2 (cyan), CK-EpCAM (white) and DAPI (blue). H\&E, IHC and MIHC were used to stain serial sections. Magnification: $200 \times$. 
Table 1. Summary of CTAs in TNBC.

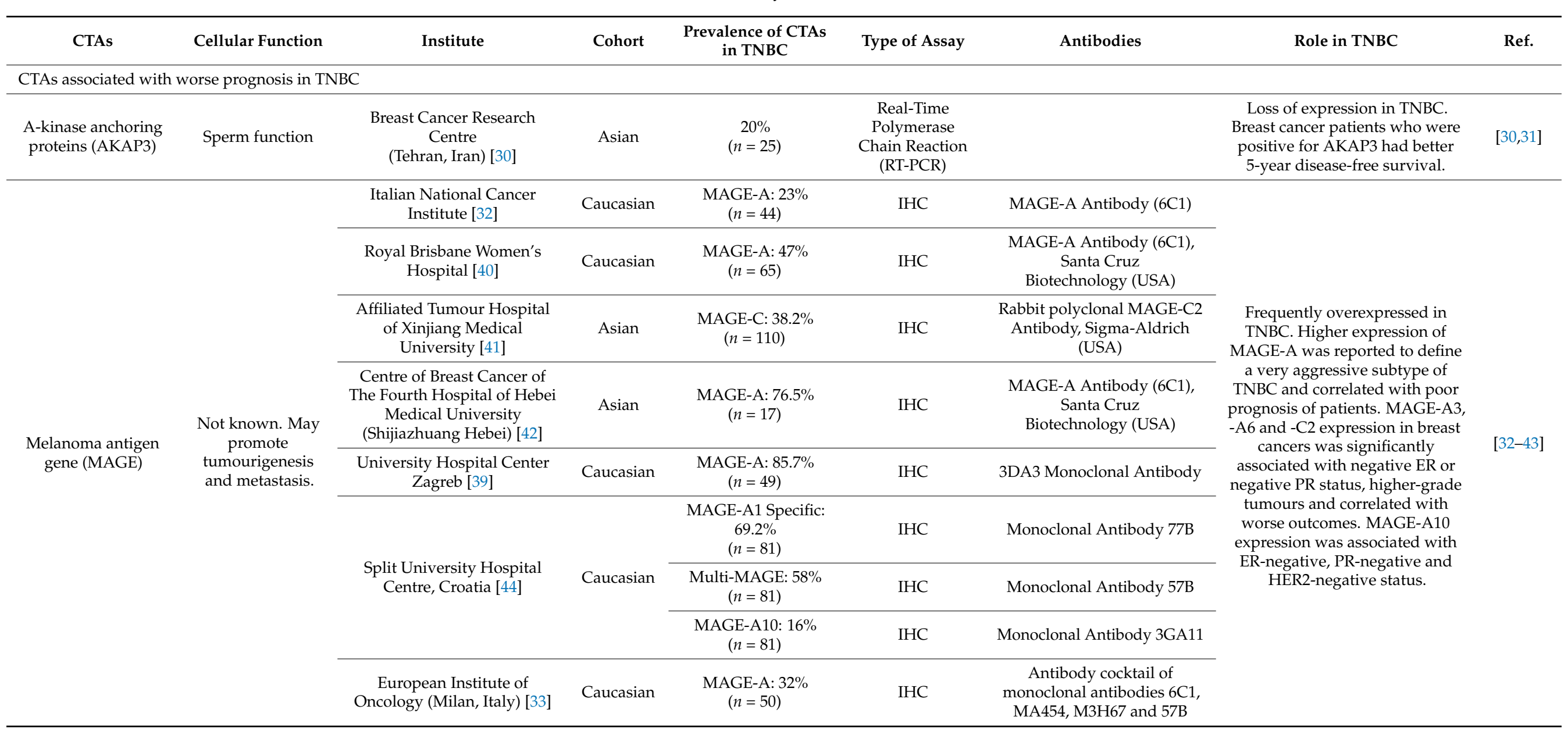


Table 1. Cont.

\begin{tabular}{|c|c|c|c|c|c|c|c|c|}
\hline CTAs & Cellular Function & Institute & Cohort & $\begin{array}{l}\text { Prevalence of CTAs } \\
\text { in TNBC }\end{array}$ & Type of Assay & Antibodies & Role in TNBC & Ref. \\
\hline & & $\begin{array}{c}\text { Copenhagen University } \\
\text { Hospital [45] }\end{array}$ & Caucasian & $\begin{array}{l}\text { MAGE-A: } 33 \% \\
\quad(n=78)\end{array}$ & $\mathrm{IHC}$ & $\begin{array}{c}\text { Rabbit polyclonal } \\
\text { anti-peptide antibody } \\
\text { EP101638 (rab Ab 1982) } \\
\text { raised against Mage-4, } \\
\text { Eurogentec (Belgium) }\end{array}$ & & \\
\hline & & $\begin{array}{l}\text { National Cancer Institute } \\
\text { (Milan, Italy) [43] }\end{array}$ & Caucasian & $\begin{array}{l}\text { MAGE-A: } 85.7-93 \% \\
\qquad(n=21)\end{array}$ & $\mathrm{IHC}$ & $\begin{array}{l}\text { MAGE-A3 (Clone 60054-1-Ig) } \\
\text { Monoclonal Antibody, } \\
\text { Proteinthec (USA) }\end{array}$ & & \\
\hline \multirow{2}{*}{ Mesothelin (MSLN) } & \multirow{2}{*}{$\begin{array}{l}\text { GPI-anchored } \\
\text { membrane protein }\end{array}$} & $\begin{array}{c}\text { Perelman School of Medicine, } \\
\text { University of } \\
\text { Pennsylvania [46] }\end{array}$ & Caucasian & $\begin{array}{c}67 \% \\
(n=99)\end{array}$ & $\mathrm{IHC}$ & $\begin{array}{c}\text { Mesothelin Monoclonal } \\
\text { Antibody (clone 5B2), } \\
\text { Thermo Scientific (USA) }\end{array}$ & \multirow{2}{*}{$\begin{array}{l}\text { MSLN is significantly expressed } \\
\text { in TNBC compared to non-TNBC } \\
\text { and is an independent prognostic } \\
\text { marker associated with distant } \\
\text { metastasis and worse survival. }\end{array}$} & \multirow{2}{*}[46-48]{} \\
\hline & & $\begin{array}{c}\text { University of Texas MD } \\
\text { Anderson Cancer Center [48] }\end{array}$ & Caucasian & $\begin{array}{c}34 \% \\
(n=109)\end{array}$ & $\mathrm{IHC}$ & $\begin{array}{l}\text { Mesothelin Monoclonal } \\
\text { Antibody (clone 5B2), } \\
\text { Novocastra (USA) }\end{array}$ & & \\
\hline $\begin{array}{l}\text { Prostate stem cell } \\
\text { antigen (PSCA) }\end{array}$ & $\begin{array}{l}\text { GPI-anchored } \\
\text { membrane protein }\end{array}$ & $\begin{array}{l}\text { University Hospital of } \\
\text { Dresden, Germany [49] }\end{array}$ & Caucasian & $\begin{array}{c}17 \% \\
(n=90)\end{array}$ & $\mathrm{IHC}$ & PSCA antibody MB1 & $\begin{array}{l}\text { Distribution of PSCA expression } \\
\text { among TNBC was comparable to } \\
\text { the total population. Patients } \\
\text { with PSCA-positive invasive } \\
\text { micropapillary carcinoma (IMPC) } \\
\text { of the breast had decreased } \\
\text { disease-free survival. }\end{array}$ & {$[49,50]$} \\
\hline $\begin{array}{l}\text { Receptor tyrosine } \\
\text { kinase-like orphan } \\
\text { receptor } 2 \text { (ROR2) }\end{array}$ & $\begin{array}{l}\text { Tyrosine kinase } \\
\text { receptor family }\end{array}$ & $\begin{array}{c}\text { University of New South } \\
\text { Wales [51] }\end{array}$ & Caucasian & $\begin{array}{c}87 \% \\
(n=295, \text { breast } \\
\text { cancer including } \\
\text { triple- negative) }\end{array}$ & $\mathrm{IHC}$ & $\begin{array}{l}\text { Human ROR2 polyclonal } \\
\text { antibody, Sigma-Aldrich } \\
\text { (Australia) }\end{array}$ & $\begin{array}{l}\text { Breast cancer patients including } \\
\text { TNBC expressing ROR2 had } \\
\text { significantly worse prognoses } \\
\text { with shorter overall survival } \\
\text { compared to those lacking ROR2. }\end{array}$ & [51] \\
\hline $\begin{array}{l}\text { Sperm protein } \\
\text { associated with the } \\
\text { nucleus X-linked } \\
\text { (SPANX) }\end{array}$ & Sperm function & $\begin{array}{l}\text { University of Texas Health } \\
\text { Science Center [52] }\end{array}$ & Caucasian & $\begin{array}{c}73 \% \\
(n=15)\end{array}$ & $\mathrm{IHC}$ & $\begin{array}{c}\text { SPANXB1 (\#H00728695), } \\
\text { Abnova (Taiwan) }\end{array}$ & $\begin{array}{c}\text { SPANXB1 was frequently } \\
\text { overexpressed in human primary } \\
\text { and metastatic TNBC. In } \\
\text { ER-negative patients, elevated } \\
\text { SPANX-A/C/D was correlated } \\
\text { with shorter distant } \\
\text { metastasis-free survival time. }\end{array}$ & {$[52,53]$} \\
\hline
\end{tabular}


Table 1. Cont.

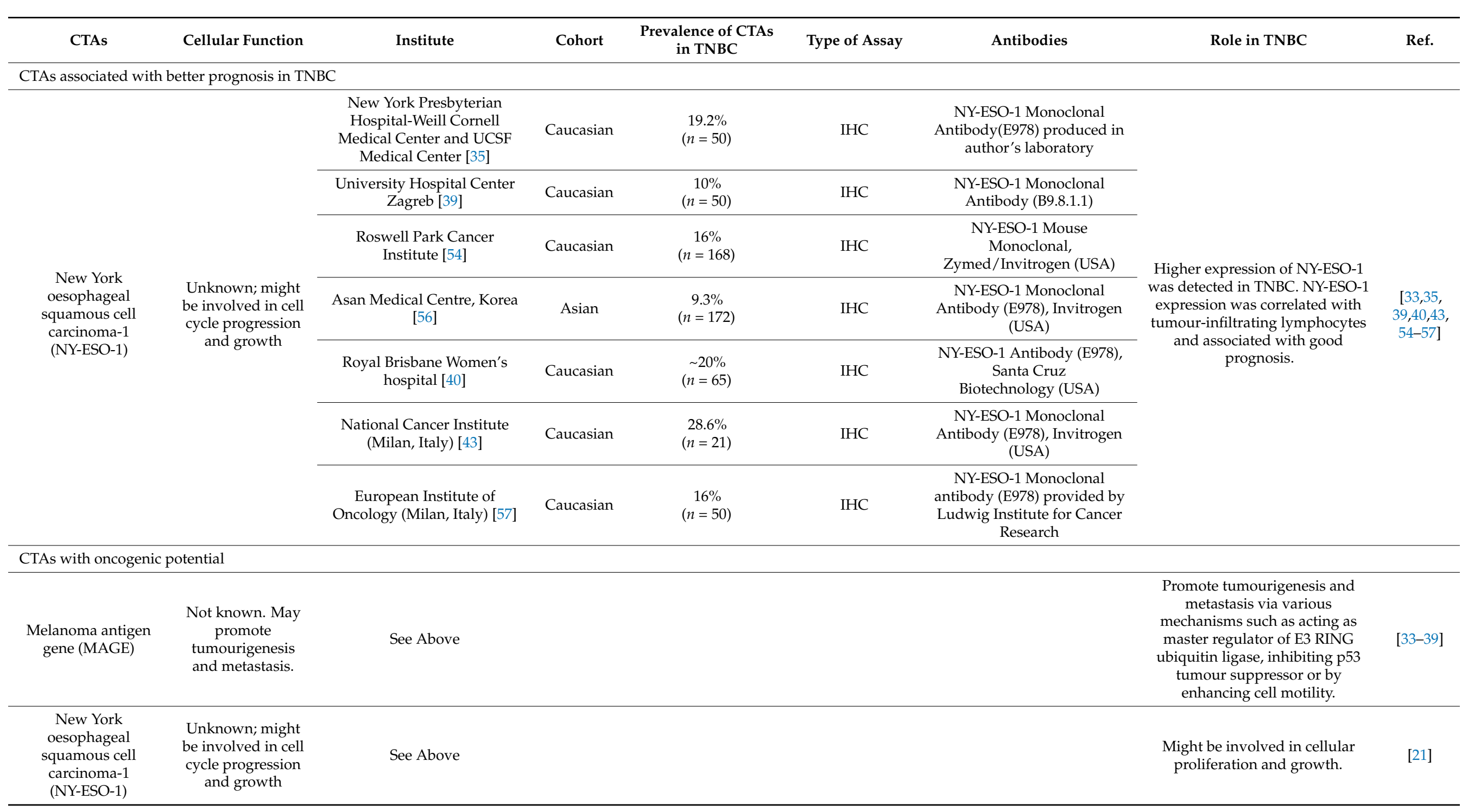


Table 1. Cont.

\begin{tabular}{|c|c|c|c|c|c|c|c|c|}
\hline CTAs & Cellular Function & Institute & Cohort & $\begin{array}{l}\text { Prevalence of CTAs } \\
\text { in TNBC }\end{array}$ & Type of Assay & Antibodies & Role in TNBC & Ref. \\
\hline $\begin{array}{c}\text { Preferentially } \\
\text { expressed antigen of } \\
\text { melanoma (PRAME) }\end{array}$ & $\begin{array}{l}\text { Membrane-bound } \\
\text { protein }\end{array}$ & $\begin{array}{l}\text { National Cancer Institute } \\
\text { (Milan, Italy) [43] }\end{array}$ & Caucasian & $85.7-96.6 \%(n=21)$ & $\mathrm{IHC}$ & $\begin{array}{l}\text { PRAME Polyclonal Antibody } \\
\text { (Clone NBP1-85418), Novus } \\
\text { Boilogicals (USA) }\end{array}$ & $\begin{array}{c}\text { Role in EMT reprogramming. } \\
\text { Expression of PRAME was } \\
\text { associated with negative } \\
\text { ER status. }\end{array}$ & [58-60] \\
\hline $\begin{array}{l}\text { Sperm-associated } \\
\text { antigen } 9 \text { (SPAG9) }\end{array}$ & Sperm function & $\begin{array}{l}\text { National Institute of } \\
\text { Immunology, Aruna Asaf Ali } \\
\text { Marg, (New Delhi, India) [61] }\end{array}$ & Asian & NA & IHC & $\begin{array}{l}\text { Polyclonal antibody to } \\
\text { SPAG9 was prepared in } \\
\text { authors' laboratory }\end{array}$ & $\begin{array}{l}\text { Analysis of } 100 \text { breast cancer } \\
\text { tissues ( } 94 \text { infiltrating ductal } \\
\text { carcinomas [IDC], } 2 \text { ductal } \\
\text { carcinomas in situ [DCIS] and } 4 \\
\text { invasive lobular carcinomas } \\
\text { [ILC]) revealed that } 88 \% \text { of } \\
\text { samples stained positive for } \\
\text { SPAG9. Role in invasiveness of } \\
\text { breast cancer. Downregulation } \\
\text { could reduce invasive potential } \\
\text { of TNBC. }\end{array}$ & {$[61,62]$} \\
\hline $\begin{array}{l}\text { Sperm protein } \\
\text { associated with the } \\
\text { nucleus X-linked } \\
\text { (SPANX) }\end{array}$ & Sperm function & See Above & & & & & $\begin{array}{l}\text { Required for metastasis. Interacts } \\
\text { with lamin } \mathrm{A} / \mathrm{C} \text { at the inner } \\
\text { nuclear membrane and involved } \\
\text { in the formation of actin-rich } \\
\text { cellular protrusions that } \\
\text { reorganise the } \\
\text { extracellular matrix. }\end{array}$ & {$[52,53]$} \\
\hline $\begin{array}{c}\text { Testes-specific } \\
\text { protease } 50 \text { (TSP50) }\end{array}$ & Oncogene & $\begin{array}{l}\text { Northeast Normal University } \\
\text { (Changchun, China) }\end{array}$ & Caucasian & NA & $\mathrm{IHC}$ & $\begin{array}{l}\text { TSP50 Monoclonal Antibody } \\
\text { was prepared in authors' } \\
\text { laboratory }\end{array}$ & $\begin{array}{l}\text { Analysis of } 88 \text { clinical breast } \\
\text { cancer tissue microarrays (BR955 } \\
\text { and BR } 1101 \text { from US Biomax, } \\
\text { Rockville, MD, USA) revealed } \\
\text { that } 90.9 \% \text { of specimens stained } \\
\text { positive for TSP50 compared to } \\
10 \% \text { of adjacent normal tissues. } \\
\text { Role in cell growth. Knockdown } \\
\text { of TSP50 in breast cancer cells } \\
\text { significantly inhibits cellular } \\
\text { proliferation. TSP50-positive } \\
\text { tumours were associated with } \\
\text { negative ER expression and } \\
\text { higher grade. }\end{array}$ & {$[63,64]$} \\
\hline
\end{tabular}


Table 1. Cont.

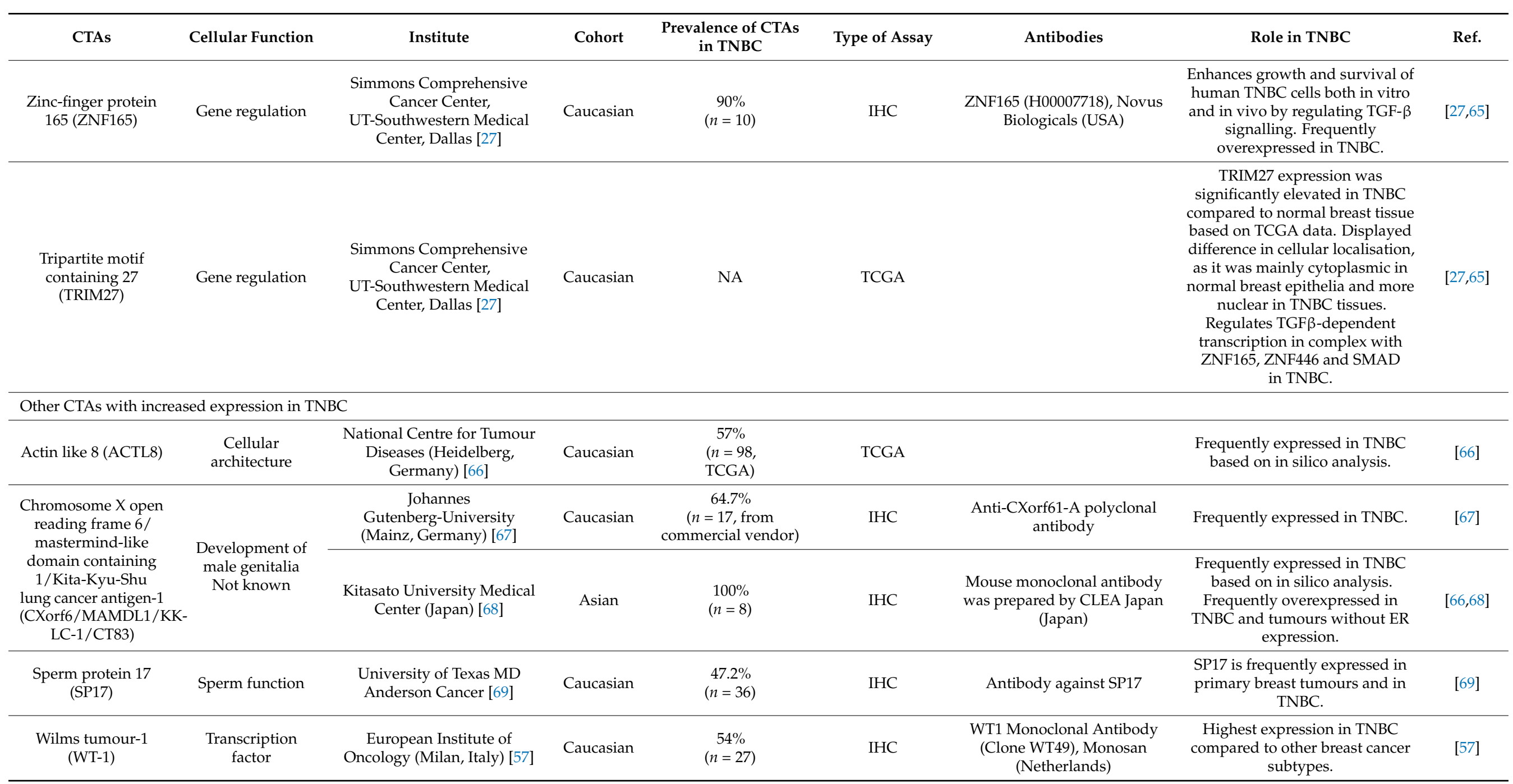




\subsection{CTAs Associated with Worse Outcome in TNBC}

Several CTAs are frequently overexpressed in TNBC and have shown correlation with poorer patient outcomes (Figure 1, Table 1). One prominent example is the melanoma antigen gene (MAGE) family, which has over 60 proteins divided into Type I (MAGE-A, B and $C$ subfamilies) or Type II (MAGE-D, $-E,-F,-G,-H,-L$ and necdin) depending on the positions of their genes in relation to the $\mathrm{X}$-chromosome [70-72].

MAGE-A is frequently expressed in solid tumours such as non-small cell lung cancer (NSCLC), bladder cancer, oesophageal and head and neck cancers, sarcomas and TNBC [73]. A meta-analysis of 7428 patients and 44 studies found that high MAGE-A expression was significantly correlated with worst outcomes for various solid cancers such as lung, gastrointestinal, breast and ovarian cancers [71]. In addition, several groups also found higher expression of MAGE-A and NY-ESO-1 in ER-negative versus ER-positive breast cancers $[33,34]$. Immunohistochemistry (IHC) analysis of eight CT antigens, including MAGE-A and NY-ESO-1, also showed remarkably higher expression in ER-negative versus ER-positive human breast cancers [35]. Higher expression of MAGE-A was reported to define a very aggressive subtype of TNBC and to be associated with poor outcomes [36]. In other studies, MAGE-A3,-A6 and -C2 expression levels in breast cancers were significantly correlated with parameters such as ER-negative or PR-negative status, tumour grade and outcome, while MAGE-A10 expression was associated with TNBC status [37-39].

Interestingly, the expression of MAGE was higher compared to that of NY-ESO-1 in TNBC, with values ranging from $22 \%$ to $93 \%$ (Table 1). Curigliano et al. observed higher MAGE-A levels in TNBC (32\%) compared to ER-positive breast cancer samples $(10 \%)$ [33]. The findings were corroborated by another study which reported higher MAGE-A expression in TNBC (85.7\%) compared to ER ${ }^{+} \mathrm{PR}^{+} \mathrm{HER} 2^{-}$breast cancer samples (55.5\%) [39].

The mesothelin (MSLN) gene encodes a glycosylphosphatidylinositol (GPI)-anchored membrane protein, which gives rise to MSLN and a soluble product, known as megakaryocyte potentiating factor, upon cleavage [74]. MSLN is expressed on the membrane of mesothelial cells of the peritoneal and pleural cavities, and overexpression of MSLN has been observed in mesothelioma, ovarian, lung, oesophageal, endometrial and breast cancers [75]. MSLN was significantly expressed in TNBC compared to non-TNBC tissues and was an independent prognostic marker associated with distant metastasis and worse survival (Figure 1, Table 1) [47].

Prostate stem cell antigen (PSCA) is a member of the Thy- $1 /$ Ly- 6 family that encodes a 123-amino acid GPI-anchored cell surface protein (Table 1) [49]. Upregulated PSCA expression was found in breast cancer patients and was associated with unfavourable histopathological grade, increased Ki67 proliferation index and HER2/neu receptor status [49]. Patients with PSCA-positive invasive micropapillary carcinoma (IMPC) of the breast had decreased DFS compared to PSCA-negative IMPC patients [50].

Receptor tyrosine kinase-like orphan receptor 2 (ROR2), a novel Wnt receptor, belongs to the tyrosine kinase receptor family, which is important in regulating skeletal and neuronal development, cell migration and cell polarity (Table 1) [76]. Breast cancer patients, including those with TNBC expressing ROR2, experienced a significantly worse prognosis with shorter overall survival compared to those lacking ROR2 [51].

Sperm protein associated with the nucleus X-linked (SPANX) is a CTA with a role in spermatogenesis (Table 1) [77]. High nuclear and cytoplasmic SPANXB1 expression patterns were observed in 73\% (11/15) of human primary and metastatic TNBC tissues in contrast to normal tissues [52]. SPANX-A/C/D enhanced the metastasis of ER-negative breast cancer cells, and high SPANX-A/C/D levels in breast cancer tumours correlated with poor prognosis, with increasing SPANX-A/C/D levels being associated with a shorter distant metastasis-free survival time in ER-negative patients [53].

A-kinase anchoring proteins (AKAP) are a group of CTAs involved in sperm function (Table 1) [78]. AKAP3 expression was deficient in TNBC, and patients with AKAP3-positive TNBC have a better 5-year DFS [30]. 


\subsection{CTAs Associated with Improved Outcome in TNBC}

The CTA New York oesophageal squamous cell carcinoma-1 (NY-ESO-1), also known as cancer-testis antigen 1B (CTAG1B), is immunogenic and reportedly induces specific B-cell and T-cell immunity in patients with NY-ESO-1-expressing cancers [79]. NY-ESO1 was not frequently expressed in non-TNBC, with expression levels ranging from $0 \%$ to $12.5 \%[33,35,39,40,43,54,56,57]$. In contrast, expression levels of NY-ESO-1 in TNBC ranged from $9.3 \%$ to $28.6 \%$ (Table 1 ). NY-ESO-1 was preferentially detected in TNBC compared with ER-positive tumours, with NY-ESO-1 expression reported in nine (18\%) TNBC compared to two (4\%) ER-positive tumours [33]. Consistent with these findings, a separate study noted the expression of NY-ESO- 1 in $16 \%$ of TNBC compared with only $2 \%$ in ER-positive tumours, and 8 out of 11 (72.7\%) patients with NY-ESO-1+ TNBC had measurable antibody responses to NY-ESO-1 [54]. NY-ESO-1 levels correlated with the number of tumour-infiltrating lymphocytes (TILs) and were also associated with good prognosis in 1234 TNBC samples [56]. Taken together, the study findings suggest that NYESO-1 is commonly expressed at high levels in TNBC and TBNCs expressing higher levels of NY-ESO-1 tend to have a better prognosis than TNBCs with lower levels of expression.

\subsection{CTAs with Oncogenic Potential}

CTAs have been involved in various processes of tumourigenesis and metastasis, such as epithelial-mesenchymal transition (EMT), proliferation, apoptosis and invasion (Table 1). MAGE-A has been implicated in highly aggressive behaviour and EMT in TNBC [42]. Analysis of 120 female breast cancer patients who underwent mastectomy revealed higher MAGE-A staining in TNBC (76.47\%, 13/17), which was significantly correlated with ERnegative, PR-negative and HER-2-negative statuses, lymph node involvement and higher histological grade [42]. A reduction in MAGE-A was associated with increases in epithelial markers and declines in mesenchymal characteristics [42]. The biological functions of MAGE-A family members have not been fully elucidated, but various reports suggest that MAGE proteins can promote tumourigenesis and metastasis via different mechanisms, such as acting as a master regulator of E3 RING ubiquitin ligase, by inhibiting p53 tumour suppressor or by enhancing cell motility $[80,81]$. Similarly, very little is known about the biological functions of NY-ESO-1, with some reports suggesting that it might be involved in cell cycle progression and growth [21].

Preferentially expressed antigen of melanoma (PRAME) encodes a membrane-bound protein that promotes autologous cytotoxic T-cell-mediated immune responses (Table 1) [82]. An analysis of 295 breast cancer patients revealed that higher expression of PRAME was associated with poorly differentiated tumours, and PRAME expression was related to ER levels, as ER-negative patients had higher PRAME expression, whereas ER-positive patients had low PRAME expression [58]. PRAME expression was reported to be higher in basal-like breast cancer subtypes than other subtypes [59]. In addition, PRAME reportedly plays a role in tumourigenesis in TNBC through EMT-related gene reprogramming [60].

SPANX-A/C/D was discovered as an important factor for the metastasis of breast cancer cells; it was hypothesised to act via interactions with components of the cytoskeleton at the inner nuclear membrane and is required to produce actin-rich cellular protrusions during modelling of the extracellular matrix (Table 1). Sperm-associated antigen 9 (SPAG9) mRNA and protein expression was found in the cytoplasm of all examined breast cancer cells, including TNBC cells (Table 1) [62]. Interestingly, the downregulation of SPAG9 ameliorated the invasiveness of TNBC [62].

Zinc-finger protein 165 (ZNF165) is a member of the SCAN- $\left(\mathrm{C}_{2} \mathrm{H}_{2}\right)_{\mathrm{n}}$ sub-family of zincfinger proteins and is predominantly found in the nucleus where it interacts with proteins involved in gene-regulatory activity (Table 1) [27]. ZNF165 is frequently overexpressed in TNBC and interacts with SMAD3 to promote the mitosis and survival of human TNBC cells by controlling the transcription of transforming growth factor $\beta$ (TGF $\beta$ )-dependent genes both in vitro and in vivo [65]. The tripartite motif-containing 27 (TRIM27) gene encodes the RING finger protein (RFP), a member of the tripartite motif family that is involved in gene 
regulation [65]. TRIM27 was found to be critical for the transcriptional activity of ZNF165 in promoting tumour growth in TNBC. Higher expression of TRIM27 was reported in TNBC compared to normal breast tissue using data from The Cancer Genome Atlas (TCGA) [65]. Interestingly, TRIM27 exhibited different subcellular localisation with transformation, with higher nuclear expression in TNBC, suggesting that the transcriptional activity of TRIM27 might be associated with the transformed state [65].

Testes-specific protease 50 (TSP50) is an oncogene that promotes breast cancer survival, invasion and metastasis via the activation of the NF-KB signalling pathway (Table 1) [6]. Knockdown of TSP50 in breast cancer cells significantly inhibited cellular proliferation [64]. The levels of TSP50 together with the expression of p65 and matrix metalloproteinase 9 (MMP9) were analysed in conjunction with clinicopathological features, such as tumour size, pathologic grade, ER and PR levels, in breast cancer tissues [63], and the majority of TSP50+/ p65+ tumours (72\%) and TSP50+/MMP9+(78\%) tumours were negative for ER expression and tended to be of a higher grade [63].

\subsection{CTAs with Increased Expression in TNBC but with Unclear Implications}

Some CTAs display increased expression in TNBC, but their significance has not been clearly defined. In large-scale in silico analyses, actin-like 8 (ACTL8), which is the building block for the intracellular architecture of cells, was expressed in $57 \%$ of TNBC, while KitaKyushu lung cancer antigen-1 (KK-LC-1), also known as cancer-testis antigen 83 (CT83), chromosome $\mathrm{X}$ open reading frame 6 (CXorf6), or mastermind-like domain containing 1 (MAMLD1), was expressed in 65\% of TNBC [66]. KK-LC-1/CT83/ CXorf6/MAMLD1 was found to be a critical gene in hypospadias and plays a less important role in testosterone production during the critical time for sex development [83,84]. KK-LC-1 was found in all TNBC tumours and all tumours without ER expression, with gene and protein expressions of $11.8 \%$ and $52.9 \%$, respectively [68]. In another study, it was found that $53 \%$ of TNBC patients expressed CXorf 61 in at least $30 \%$ of their tumour cells, whereas expression was strictly restricted to the testes in normal human tissues (Table 1) [67]. CXorf61 has the potential to induce a strong immune response, as high frequencies of CXorf61-specific $\mathrm{T}$ cells could be obtained by vaccinating HLA- ${ }^{*} 02$-transgenic mice with CXorf61-encoding RNA, and in vitro priming of human CD8+ T cells derived from a healthy donor recognizing CXorf6166-74 induced a strong antigen-specific immune response [67].

Sperm protein 17 (SP17) is involved in various stages of spermiogenesis, and aberrant SP17 expression has been linked to cancers such as ovarian, oesophagus, central nervous system, multiple myeloma and esthesioneuroblastoma (Table 1) [85-90]. The exact role of SP17 in cancer cells has not yet been elucidated, with some reports suggesting that SP17 promotes cell-cell adhesion in malignant B-lymphocytes via interaction with heparansulphate and enhances cell movement and drug resistance in ovarian cells [91,92]. SP17 was preferentially expressed in breast cancer cell lines and primary breast tumours, including TNBC, compared to non-tumoural breast tissue [69]. Specific anti-SP17 antibodies were also discovered in patients' sera, and the generation of SP17-specific, HLA class I-restricted, cytotoxic T-lymphocytes led to the death of breast cancer cells, opening the possibility that SP17 could be a valid target for TNBC immunotherapy [69].

Wilms tumour antigen (WT-1) is a transcription factor containing four zinc-finger motifs at the C-terminus and a proline or glutamine-rich DNA-binding domain at the $\mathrm{N}$-terminus [93]. Out of all breast cancer subtypes examined, TNBC had the highest WT1 expression, with WT1 expression (score $>2+$ ) being recorded in $27(54 \%)$ TNBC cases, but only $6(12 \%)$ and $3(6 \%)$ of ER-positive and HER2-positive tumour cases, respectively (Table 1) [57].

\section{Future Potential Application of CTAs Clinically}

3.1. Future Potential Application of CTAs in Screening Workflow in Clinical Practice

As summarised in Table 1, majority of laboratories evaluated CTAs expressions in breast tissues with IHC platform using commercially available antibodies. It is possi- 
ble to develop assays in the clinical settings using these antibodies. Conventional IHC is cost- effective, easy to execute and frequently performed to visualise expression patterns in human biopsy samples. However, there are limitations to the number of markers that can be evaluated in each tissue sample. Several technologies such as multiplex IHC/immunofluorescence(mIHC/IF), imaging mass cytometry, multiplex ion beam imaging, single-cell RNA sequencing have emerged to circumvent the limitations. Extensive reviews on these emerging technologies have also been discussed [94-96].

Multiple laboratories have utilised $\mathrm{mIHC} / \mathrm{IF}$ to evaluate biomarkers in several cancers. Systematic review and meta-analysis of tumour patients from 8135 patients revealed that $\mathrm{mIHC} / \mathrm{IF}$ had superior diagnostic accuracy in predicting clinical response to antiPD-1/PD-L1 therapy than PD-L1 IHC, tumour mutational burden or gene expression profiling [97]. An optimised mIHC/IF protocol was developed for PD-L1 testing in TNBC which demonstrated good correlation with conventional IHC, thus providing further evidence for the feasibility of incorporating $\mathrm{mIHC} / \mathrm{IF}$ in clinical practice [98]. A recent multisite study comparing mIF on PD-1/PD-L1 axis on tonsil and breast carcinoma and non-small cell lung cancer (NSCLC) demonstrated good reproducibility and sensitivity across multiple institutions which included Johns Hopkins University, Yale University, MD Anderson Cancer Center, Earle A. Chiles Research Institute, Akoya Biosciences and Bristol-Myers Squibb [99]. Standardisation, validation and reproducibility of end-to-end workflow across multiple sites and clinical laboratory processes are important to promote translation of $\mathrm{mIHC} / \mathrm{IF}$ technology to clinical practice. The evidence from feasibility studies have been encouraging, and more research could be done in this area to translate emerging technologies to clinical practice. Recently, a high throughput system to analyse tissue microarrays of breast cancer samples using multiplexed microfluidic IHC to generate biomarker barcodes have been developed [100]. The biomarker barcode of breast cancer patient-derived tissue microarrays was compared to traditional method of breast cancer diagnosis, thus opening the possibility of high-throughput screening with diagnostic capability.

Advances in next-generation sequencing (NGS) technology have identified unrecognised gene expressions and somatic mutations in TNBC samples, thus allowing refinement of TNBC subtypes at the genomic level and the possibility of identifying novel targets for personalised therapy [101]. Using an expanded 358-gene NGS assay, JAX-CTP ${ }^{\mathrm{TM}}$ assay on the Illumina HiSeq 2500 or MiSeq sequencers, additional clinically relevant genetic variants were identified in TNBC, thus enlarging the possibility for additional therapeutic interventions and clinical trial eligibility for these patients [102]. To investigate the clinical value of whole genome sequencing (WGS) in improving TNBC patient stratification, 254 TNBCs were sequenced under the Sweden Cancerome Analysis Network-Breast (SCANB) study [103]. Homologous Recombination Deficiency Detect (HRDetect) mutationalsignature-based algorithm was used to classify tumours, with HRDetect-high patients having better invasive disease-free survival and distant relapse-free interval on adjuvant chemotherapy compared to HRDetect-low and HRDetect-intermediate having the poorest outcome [103]. There are several advantages in utilising WGS or NGS in routine diagnostic settings such as better TNBC patient stratification by identifying different groups with different survival likelihoods compared to classification by individual mutations, identifying poorer responders to current standard of care that are not identified by other method, identifying tumours that do not have genetic/epigenetic drivers but might have good outcome.

Current evidence suggests that CTAs are a common feature of TNBC and may correlate with prognosis of patients with TNBC. At present, TNBC samples are not routinely screened for CTAs expressions. The expression and characteristics of CTAs in TNBC provide exciting possibilities to enhance current screening, diagnosis and treatment methods (Figure 2). We propose utilising conventional IHC or multiplex staining platform to evaluate CTAs in evaluation of TNBC samples. Genomics study using microarrays or NGS could also be applied to identify new or unique CTAs or molecular signatures in TNBC for better patient 
stratifications. We propose that application of enhanced screening in clinical practise would lead to quicker diagnosis, early detection of cancer, better patient stratification and identification of good or bad responders to treatments. The overall goal is to contribute to better treatment outcome and personalised medical therapy for patients with TNBC. This is important as TNBC is a heterogenous cancer with limited treatment options. While technologies such as mIHC/IF or NGS/WGS hold great promise to be translated to clinical practice, substantial barriers such as cost, technical issues and development of reliable and reproducible quality assurance and quality control prevent widespread adoption in clinical practice. While there is growing body of evidence applying these technologies clinically, more effort could be performed for widespread adoption and to take advantage of the technologies in clinical practice. A group of key opinion leaders and relevant stakeholders in Italy proposed guidelines on the use of NGS tests in clinical practice based on several parameters such as tumour types, number and complexity of biomarkers and availability of treatments [104]. Recommendations for technologies such as $\mathrm{mIHC} / \mathrm{mIF}$ in clinical practice encompassing views from different expert could be collected for different cancers, encouraging growth in precision medicine.

\section{Future Clinical Applications}

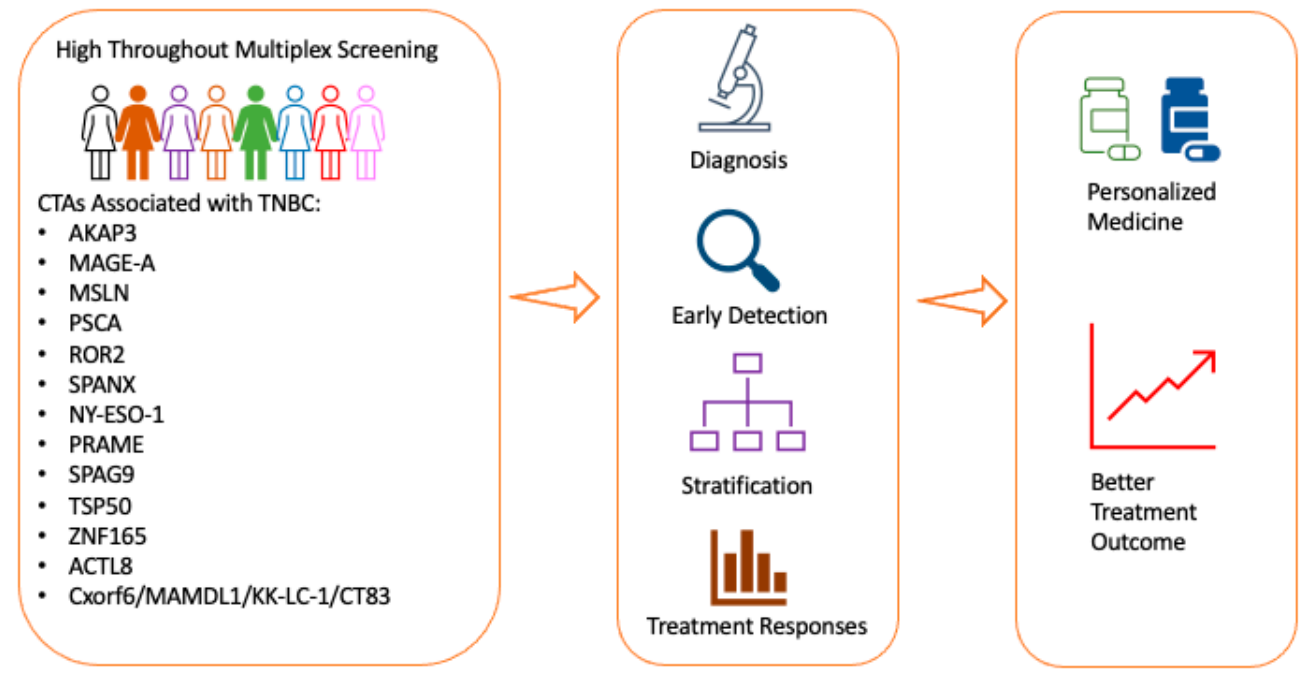

Figure 2. Potential workflow in screening for CTAs in TNBC. The expression of CTAs in TNBC provides great promise for enhancing current screening, diagnosis and treatment methods. TNBC: triple-negative breast cancer; CTA: cancer-testis antigens.

\subsection{Therapeutic Application of CTAs}

CTAs such as NY-ESO-1, MAGE, MSLN, SPANXB1, PRAME, ZNF165, TRIM27, KKLC-1, SP17 and WT-1 were found to be enriched in TNBC compared to non-TNBC tissue (Table 1). The specific enrichment of CTAs opens the possibility of CTAs as targets for personalised treatments or for identifying subtypes of patients with better or worse prognosis. In addition, CTAs are immunogenic, thus providing opportunities for development of therapeutic vaccines and are attractive targets for immunotherapy. Given the growing evidence of their roles in TNBC, CTAs are potential targets for therapeutic intervention. Several clinical trials are currently being conducted to evaluate the effectiveness of CTAs, such as NY-ESO-1, MAGE, MSLN, PRAME, PSCA, ROR2 and WT1, as treatment targets in breast cancers and other solid tumours (Table 2). CTAs are being widely developed as cancer vaccine, T-cell immunotherapy and antibody-based therapy in breast cancer including TNBC (Table 2). Other CTAs are also evaluated in clinical trials as single therapy or combination therapy in other cancer types, highlighting the attractiveness of CTAs as potential therapeutic strategy for cancers [105]. 
Table 2. Summary of clinical trials involving CTAs with a focus on breast cancer.

\begin{tabular}{|c|c|c|c|c|c|c|}
\hline Target & $\begin{array}{l}\text { Clinical Trials.Gov } \\
\text { Identifier }\end{array}$ & Type & Drug Details & Phase & $\begin{array}{l}\text { Recruitment } \\
\text { Status }\end{array}$ & $\begin{array}{c}\text { Breast Cancer Subtypes/Other } \\
\text { Cancers }\end{array}$ \\
\hline \multirow{11}{*}{ NY-ESO-1 } & NCT03093350 & T-cell immunotherapy & $\begin{array}{l}\text { Tumour-associated antigen (TAA)-specific } \\
\text { cytotoxic T- lymphocytes targeting NY-ESO-1, } \\
\text { MAGEA4, PRAME, survivin and SSX2 }\end{array}$ & Phase II & $\begin{array}{l}\text { Active, not } \\
\text { recruiting }\end{array}$ & $\begin{array}{l}\text { Metastatic or locally recurrent } \\
\text { unresectable breast cancer }\end{array}$ \\
\hline & NCT02015416 & Cancer vaccine & $\begin{array}{l}\text { IDC-G305: immunotherapy consisting of } \\
\text { recombinant NY-ESO-1 antigen and the adjuvant } \\
\text { GLA-SE }\end{array}$ & Phase I & Completed & $\begin{array}{l}\text { Breast cancer, melanoma, ovarian } \\
\text { cancer, sarcoma or NSCLC }\end{array}$ \\
\hline & NCT01522820 & Cancer vaccine & $\begin{array}{l}\text { DEC-205/NY-ESO-1 fusion protein CDX-1401 } \\
\text { with and without sirolimus }\end{array}$ & Phase I & Completed & Breast cancer, other solid tumours \\
\hline & NCT00291473 & Cancer vaccine & $\begin{array}{l}\text { Cholesterol-bearing hydrophobized pullulan } \\
\text { HER2 protein } 146 \text { (CHP-HER2) and NY-ESO-1 } \\
\text { protein (CHP-NY-ESO-1) in combination with } \\
\text { OK-432 }\end{array}$ & Phase I & Completed & $\begin{array}{l}\text { HER2- and/or NY-ESO-1-expressing } \\
\text { cancers }\end{array}$ \\
\hline & NCT01967823 & T-cell immunotherapy & $\begin{array}{l}\text { Anti-ESO mTCR-engineered peripheral blood } \\
\text { lymphocytes with high-dose aldesleukin }\end{array}$ & Phase II & Completed & $\begin{array}{l}\text { Metastatic cancer, including melanoma } \\
\text { whose tumours express the ESO antigen }\end{array}$ \\
\hline & NCT02661100 & Cancer vaccine & $\begin{array}{l}\text { CDX-1401: human monoclonal antibody specific } \\
\text { for DEC-205, fused to full-length tumour antigen } \\
\text { NY-ESO-1 in combination with poly-ICLC and } \\
\text { pembrolizumab }\end{array}$ & Phase I/II & $\begin{array}{l}\text { Withdrawn } \\
\text { (Drug } \\
\text { unavailable) }\end{array}$ & $\begin{array}{l}\text { Advanced TNBC, NSCLC, small-cell } \\
\text { lung cancer, urothelial cancer, } \\
\text { mesothelioma, malignant melanoma }\end{array}$ \\
\hline & NCT02457650 & T-cell immunotherapy & Anti-NY-ESO-1 TCR transduced T cells & Phase I & Unknown & Breast cancer, other solid tumours \\
\hline & NCT00623831 & Cancer vaccine & $\begin{array}{l}\text { mixed bacteria vaccine in patients with tumours } \\
\text { expressing NY-ESO-1 antigen }\end{array}$ & Phase I & Completed & Breast cancer, other solid tumours \\
\hline & NCT03159585 & T-cell immunotherapy & $\begin{array}{l}\text { TAEST16001: NY-ESO-1-specific TCR affinity } \\
\text { enhancing specific T-cell therapy }\end{array}$ & Phase I & Completed & $\begin{array}{c}\text { Breast cancer stage IV, other advanced } \\
\text { solid tumours }\end{array}$ \\
\hline & NCT01234012 & Cancer vaccine & $\begin{array}{l}\text { MF-001: CHP-NY-ESO-1 complex consisting of } \\
\text { recombinant NY-ESO-1 protein and cholesteryl } \\
\text { hydrophobized pullulan }(\mathrm{CHP})\end{array}$ & Phase I & Completed & $\begin{array}{c}\text { Metastatic or refractory breast cancer, } \\
\text { other solid tumours }\end{array}$ \\
\hline & NCT00948961 & Cancer vaccine & $\begin{array}{l}\text { CDX-1401 with immune stimulants such as } \\
\text { resiquimod and poly-ICLC (Hiltonol) }\end{array}$ & Phase I/II & Completed & $\begin{array}{c}\text { Advanced malignancies expressing } \\
\text { NY-ESO-1 }\end{array}$ \\
\hline
\end{tabular}


Table 2. Cont.

\begin{tabular}{|c|c|c|c|c|c|c|}
\hline Target & $\begin{array}{l}\text { Clinical Trials.Gov } \\
\text { Identifier }\end{array}$ & Type & Drug Details & Phase & $\begin{array}{l}\text { Recruitment } \\
\text { Status }\end{array}$ & $\begin{array}{l}\text { Breast Cancer Subtypes/Other } \\
\text { Cancers }\end{array}$ \\
\hline \multirow{4}{*}{ MAGE } & NCT04639245 & T-cell immunotherapy & $\begin{array}{c}\text { Genetically engineered cells (MAGE-A1-specific } \\
\text { T-cell receptor-transduced autologous T cells) } \\
\text { and atezolizumab }\end{array}$ & Phase I/II & Not yet recruiting & $\begin{array}{l}\text { Metastatic TNBC, urothelial cancer or } \\
\text { NSCLC }\end{array}$ \\
\hline & NCT02153905 & T-cell immunotherapy & $\begin{array}{l}\text { Autologous T cells transduced with an } \\
\text { anti-MAGE-A3 HLA-A*01-restricted TCR } \\
\text { (MAGE-A3-01) TCR and aldesleukin }\end{array}$ & Phase I/II & Terminated & $\begin{array}{l}\text { Breast cancer, cervical cancer, renal } \\
\text { cancer, melanoma, bladder cancer }\end{array}$ \\
\hline & NCT00020267 & Cancer vaccine & MAGE-12 peptide vaccine & Phase I & Completed & $\begin{array}{c}\text { Refractory metastatic cancer expressing } \\
\text { MAGE-12 antigen: Breast cancer, other } \\
\text { solid tumours }\end{array}$ \\
\hline & NCT03093350 & T-cell immunotherapy & $\begin{array}{l}\text { Tumour-associated antigen (TAA)-specific } \\
\text { cytotoxic T- lymphocytes targeting NY-ESO-1, } \\
\text { MAGEA4, PRAME, survivin and SSX2 }\end{array}$ & Phase II & $\begin{array}{l}\text { Active, not } \\
\text { recruiting }\end{array}$ & $\begin{array}{l}\text { Any breast cancer patient with } \\
\text { metastatic or locally recurrent } \\
\text { unresectable breast cancer }\end{array}$ \\
\hline PRAME & NCT00423254 & Cancer vaccine & $\begin{array}{c}\text { DNA vector pPRA-PSM with synthetic peptides, } \\
\text { E-PRA and E-PSM }\end{array}$ & Phase I & Completed & $\begin{array}{l}\text { Advanced solid malignancies: Breast } \\
\text { cancer, other solid tumours }\end{array}$ \\
\hline \multirow{5}{*}{ MSLN } & NCT02792114 & T-cell immunotherapy & $\begin{array}{l}\text { Mesothelin-specific chimeric antigen } \\
\text { receptor-positive T cells }\end{array}$ & Phase I & Recruiting & $\begin{array}{l}\text { Breast cancer, metastatic HER2-negative } \\
\text { breast cancer }\end{array}$ \\
\hline & NCT02414269 & T-cell immunotherapy & Mesothelin-targeted T cells & Phase I/II & Recruiting & $\begin{array}{l}\text { Breast cancer, malignant pleural disease, } \\
\text { mesothelioma, metastases, lung cancer }\end{array}$ \\
\hline & NCT02580747 & T-cell immunotherapy & Anti-meso-CAR vector transduced T cells & Phase I & Unknown & $\begin{array}{l}\text { TNBC, other mesothelin-positive } \\
\text { tumours }\end{array}$ \\
\hline & NCT03102320 & $\begin{array}{l}\text { Antibody-drug } \\
\text { conjugate }\end{array}$ & $\begin{array}{l}\text { Anetumab-ravtansine: mesothelin-targeting } \\
\text { antibody-drug conjugate }\end{array}$ & Phase Ib & $\begin{array}{l}\text { Active, not } \\
\text { recruiting }\end{array}$ & $\begin{array}{c}\text { TNBC, cholangiocarcinoma, } \\
\text { adenocarcinoma of the pancreas, } \\
\text { NSCLC, gastric adenocarcinoma }\end{array}$ \\
\hline & NCT02485119 & $\begin{array}{l}\text { Antibody-drug } \\
\text { conjugate }\end{array}$ & BAY94-9343: anetumab- ravtansine & Phase I & Completed & Advanced malignancies \\
\hline
\end{tabular}


Table 2. Cont.

\begin{tabular}{|c|c|c|c|c|c|c|}
\hline Target & $\begin{array}{l}\text { Clinical Trials.Gov } \\
\text { Identifier }\end{array}$ & Type & Drug Details & Phase & $\begin{array}{l}\text { Recruitment } \\
\text { Status }\end{array}$ & $\begin{array}{l}\text { Breast Cancer Subtypes/Other } \\
\text { Cancers }\end{array}$ \\
\hline PSCA & NCT03927573 & Antibody & $\begin{array}{c}\text { GEM3PSCA: PSCA-targeted bispecific antibody } \\
\text { engaging T cells }\end{array}$ & Phase I & Recruiting & $\begin{array}{l}\text { PSCA-positive cancer: urogenital tract } \\
\text { (renal, transitional cell, prostate), } \\
\text { NSCLC, breast and pancreatic cancer } \\
\text { refractory to standard treatments }\end{array}$ \\
\hline ROR2 & NCT03504488 & $\begin{array}{l}\text { Antibody-drug } \\
\text { conjugate }\end{array}$ & $\begin{array}{l}\text { Conditionally active biologic (CAB) } \\
\text { ROR2-targeted antibody-drug conjugate } \\
\text { (CAB-ROR2-ADC) }\end{array}$ & Phase I/II & Recruiting & $\begin{array}{l}\text { TNBC, locally advanced unresectable or } \\
\text { metastatic solid tumours that have } \\
\text { failed all available standard therapies, } \\
\text { NSCLC, soft tissue sarcoma }\end{array}$ \\
\hline \multirow{4}{*}{ WT1 } & NCT01220128 & Cancer vaccine & $\begin{array}{l}\text { GSK2302024A: recombinant WT1 } \\
\text { antigen-specific cancer immunotherapeutic } \\
\text { (ASCI) }\end{array}$ & Phase II & $\begin{array}{l}\text { Terminated } \\
\text { (negative phase } \\
\text { III of another } \\
\text { study product } \\
\text { from same } \\
\text { technology } \\
\text { platform) }\end{array}$ & $\begin{array}{l}\text { WT1-positive stage II or III breast } \\
\text { cancer }\end{array}$ \\
\hline & NCT02018458 & Cancer vaccine & $\begin{array}{l}\text { Cyclin B1/WT-1/CEF (antigen)-loaded dendritic } \\
\text { cell vaccination with preoperative chemotherapy }\end{array}$ & Phase I/II & Completed & TNBC, ER+/HER2-breast cancer \\
\hline & NCT03761914 & Cancer vaccine & Galinpepimut-S: WT1 analogue peptide vaccine & Phase I/II & Recruiting & $\begin{array}{c}\text { TNBC, acute myelogenous leukaemia, } \\
\text { ovarian cancer, colorectal cancer, } \\
\text { small-cell lung cancer }\end{array}$ \\
\hline & NCT01291420 & Cancer vaccine & $\begin{array}{l}\text { Autologous WT1 mRNA-transfected dendritic } \\
\text { cell vaccine }\end{array}$ & Phase I/II & Unknown & $\begin{array}{l}\text { Breast cancers, glioblastoma, renal cell } \\
\text { carcinoma, sarcomas, malignant } \\
\text { mesothelioma, colorectal tumours }\end{array}$ \\
\hline
\end{tabular}


Some trials involving NY-ESO-1 showed promising results. LV305, a third-generation lentivirus-based vector, enhances expression of NY-ESO-1 in dendritic cells, and is tested in clinical trial against several tumour types such as sarcoma, ovarian, melanoma and lung cancers [106]. Induction of antigen-specific responses were observed in more than half of sarcoma patients and was associated with improved 1-year survival [106]. G305, a recombinant NY-ESO-1 protein vaccine with glucopyranosyl lipid A (GLA), a synthetic TLR4 agonist adjuvant, in a stable emulsion (SE) could stimulate NY-ESO-1-specific antibody in $75 \%$ of patients with solid tumours expressing NY-ESO- 1 and T-cell responses in $44.4 \%$ of patients in a phase- 1 study [107]. The cancer types in this study included melanoma, ovarian cancer, synovial sarcoma, NSCLC and breast cancer. To further boost the T-cells responses in patients, combination product of LV305 and G305, CMB305, is under investigation in Phase I (NCT02387125) and Phase II (NCT02609984) clinical trials and in combination therapy with immune checkpoint blockers [108]. Vaccination with the long synthetic NY-ESO-179-108 peptide with a strong immune adjuvant generated substantial and long lasting CD8+ and CD4+ T-cell responses lasting at least one year in stage III/IV melanoma patients, permitting further development of this vaccine formulation for cancer immunotherapy [109].

Members of the MAGE-A family have been developed for T-cell therapy with favourable results. In a Phase I study involving HLA-DPB1*0401-restricted T-cell receptors (TCRs) that was designed to specifically recognise MAGE-A3 antigen, complete remission was seen in a patient with metastatic cervical cancer, and partial remission was seen in 3 patients [110]. The adoptive T-cell therapy ADP-A2M4, which has been modified to express TCR that can recognise MAGE-A4 cancer antigen, achieved responses in nine tumour types (NCT03132922) [111].

\subsection{Future Research Development}

At present, there is limited information on the effect of race or ethnicity on the expression of CTAs in TNBC. NY-ESO-1 and MAGE are the most studied, with several reports involving TNBC patient samples from different continents, races and ethnicities. However, there are currently no reports directly comparing the impact of race and ethnicity on CTAs in TNBC. Analyses of CTA1A and CTA1B expression in lung cancer using data from TCGA database showed higher expression of these CTAs in Asians compared to non-Asians [112]. More studies should be conducted to address these questions of TNBC epidemiology.

Further research could be performed to analyse expressions of CTAs with different immune infiltrates and correlate with clinicopathological characteristics, given the growing evidence of CTA having immunogenic and oncogenic properties in TNBC and promoting tumourigenesis or invasiveness (Table 1). Several CTAs are co-expressed in TNBC, and further research could be performed to delineate different CTAs molecular signatures and its prognostic value for TNBC clinically. More research could be performed to understand mechanistically the underlying biological and cellular functions of CTAs in TNBC, as well as the relationships between CTAs and hormone receptor or HER2 signalling pathways. Current evidence suggests that some CTAs reduced the effectiveness of responses to chemotherapy, and a detailed understanding of the important signalling pathways in TNBC could help in designing more efficacious drugs.

A key aspect for investigation is whether CTAs are abnormally expressed in breast tissue before malignancy occurs and if they could be used as potential biomarkers for TNBC. This would help clinicians to identify women at high risk for cancer development, thus improving screening protocols for the early detection of TNBC (Figure 2).

\section{Conclusions}

TNBC frequently expresses CTAs, and some CTA expression correlates with overall survival and prognosis. CTAs show biased expression in cancer and robust immunogenicity, thus serving as ideal targets for cancer immunotherapy. Multiple clinical trials have been conducted or are currently on-going to investigate the role of CTAs as treatment 
targets in advanced cancers, such as TBNC. Further research could be conducted to delineate the mechanism of action of CTAs in TNBC, increasing the efficacy of CTAs or in combination with other immunotherapies, identifying patients that would benefit most from the treatment and devising better drug delivery. With the collation of more data, CTAs may also be incorporated in routine screening protocols for TNBC.

Author Contributions: Conceptualisation, J.P.S.Y., P.H.T.; data curation, J.P.S.Y., P.H.T., T.Z.T., C.R.J., A.A.T., R.A.L.; writing-original draft preparation, R.A.L.; writing-review and editing, J.P.S.Y., P.H.T.; visualisation, J.P.S.Y., P.H.T., T.Z.T., C.R.J., A.A.T., R.A.L., J.X.L., J.I.; supervision, J.P.S.Y., P.H.T. All authors have read and agreed to the published version of the manuscript.

Funding: This research was funded by Singapore National Medical Research Council, grant number MOH-000323-00, OFYIRG19may-0007.

Conflicts of Interest: The authors declare no conflict of interest.

\section{References}

1. Thike, A.A.; Cheok, P.Y.; Jara-Lazaro, A.R.; Tan, B.; Tan, P.; Tan, P.H. Triple-negative breast cancer: Clinicopathological characteristics and relationship with basal-like breast cancer. Mod. Pathol. 2010, 23, 123-133. [CrossRef]

2. Badve, S.; Dabbs, D.J.; Schnitt, S.J.; Baehner, F.L.; Decker, T.; Eusebi, V.; Fox, S.B.; Ichihara, S.; Jacquemier, J.; Lakhani, S.R.; et al. Basal-like and triple-negative breast cancers: A critical review with an emphasis on the implications for pathologists and oncologists. Mod. Pathol. 2011, 24, 157-167. [CrossRef]

3. Teng, Y.H.; Thike, A.A.; Wong, N.S.; Tan, P.H. Therapeutic targets in triple negative breast cancer-Where are we now? Recent Pat. Anti Cancer Drug Discov. 2011, 6, 196-209. [CrossRef]

4. Iqbal, J.; Ginsburg, O.; Rochon, P.A.; Sun, P.; Narod, S.A. Differences in breast cancer stage at diagnosis and cancer-specific survival by race and ethnicity in the United States. JAMA 2015, 313, 165-173. [CrossRef]

5. Foulkes, W.D.; Smith, I.E.; Reis-Filho, J.S. Triple-negative breast cancer. N. Engl. J. Med. 2010, 363, 1938-1948. [CrossRef]

6. Li, Y.; Li, J.; Wang, Y.; Zhang, Y.; Chu, J.; Sun, C.; Fu, Z.; Huang, Y.; Zhang, H.; Yuan, H.; et al. Roles of cancer/testis antigens (CTAs) in breast cancer. Cancer Lett. 2017, 399, 64-73. [CrossRef]

7. Schwentner, L.; Wockel, A.; Konig, J.; Janni, W.; Ebner, F.; Blettner, M.; Kreienberg, R.; Van Ewijk, R.; Brenda Study Group. Adherence to treatment guidelines and survival in triple-negative breast cancer: A retrospective multi-center cohort study with 9156 patients. BMC Cancer 2013, 13, 487. [CrossRef]

8. Ernst, B.; Anderson, K.S. Immunotherapy for the treatment of breast cancer. Curr. Oncol. Rep. 2015, 17, 5. [CrossRef] [PubMed]

9. Goto, Y.; Thike, A.A.; Ong, C.C.H.; Lim, J.X.; Md Nasir, N.D.; Li, H.; Koh, V.C.Y.; Chen, X.Y.; Yeong, J.P.S.; Sasano, H.; et al. Characteristics, behaviour and role of biomarkers in metastatic triple-negative breast cancer. J. Clin. Pathol. 2020, 73, 147-153. [CrossRef]

10. Gole, L.; Yeong, J.; Lim, J.C.T.; Ong, K.H.; Han, H.; Thike, A.A.; Poh, Y.C.; Yee, S.; Iqbal, J.; Hong, W.; et al. Quantitative stain-free imaging and digital profiling of collagen structure reveal diverse survival of triple negative breast cancer patients. Breast Cancer Res. 2020, 22, 42. [CrossRef]

11. Seow, D.Y.B.; Yeong, J.P.S.; Lim, J.X.; Chia, N.; Lim, J.C.T.; Ong, C.C.H.; Tan, P.H.; Iqbal, J. Tertiary lymphoid structures and associated plasma cells play an important role in the biology of triple-negative breast cancers. Breast Cancer Res. Treat. 2020, 180, 369-377. [CrossRef]

12. Yeong, J.; Lim, J.C.T.; Lee, B.; Li, H.; Ong, C.C.H.; Thike, A.A.; Yeap, W.H.; Yang, Y.; Lim, A.Y.H.; Tay, T.K.Y.; et al. Prognostic value of CD8 + PD-1+ immune infiltrates and PDCD1 gene expression in triple negative breast cancer. J. Immunother. Cancer 2019, 7, 34. [CrossRef] [PubMed]

13. Yeong, J.; Lim, J.C.T.; Lee, B.; Li, H.; Chia, N.; Ong, C.C.H.; Lye, W.K.; Putti, T.C.; Dent, R.; Lim, E.; et al. High Densities of Tumor-Associated Plasma Cells Predict Improved Prognosis in Triple Negative Breast Cancer. Front. Immunol. 2018, 9, 1209. [CrossRef]

14. Iqbal, J.; Thike, A.A.; Cheok, P.Y.; Tse, G.M.; Tan, P.H. Insulin growth factor receptor-1 expression and loss of PTEN protein predict early recurrence in triple-negative breast cancer. Histopathology 2012, 61, 652-659. [CrossRef] [PubMed]

15. Thike, A.A.; Yong-Zheng Chong, L.; Cheok, P.Y.; Li, H.H.; Wai-Cheong Yip, G.; Huat Bay, B.; Tse, G.M.; Iqbal, J.; Tan, P.H. Loss of androgen receptor expression predicts early recurrence in triple-negative and basal-like breast cancer. Mod. Pathol. 2014, 27, 352-360. [CrossRef]

16. Thike, A.A.; Tan, P.H.; Ikeda, M.; Iqbal, J. Increased ID4 expression, accompanied by mutant p53 accumulation and loss of BRCA1/2 proteins in triple-negative breast cancer, adversely affects survival. Histopathology 2016, 68, 702-712. [CrossRef]

17. Cheung, S.Y.; Boey, Y.J.; Koh, V.C.; Thike, A.A.; Lim, J.C.; Iqbal, J.; Tan, P.H. Role of epithelial-mesenchymal transition markers in triple-negative breast cancer. Breast Cancer Res. Treat. 2015, 152, 489-498. [CrossRef]

18. Scanlan, M.J.; Gordon, C.M.; Williamson, B.; Lee, S.Y.; Chen, Y.T.; Stockert, E.; Jungbluth, A.; Ritter, G.; Jager, D.; Jager, E.; et al. Identification of cancer/testis genes by database mining and mRNA expression analysis. Int. J. Cancer 2002, 98, 485-492. [CrossRef] 
19. Simpson, A.J.; Caballero, O.L.; Jungbluth, A.; Chen, Y.T.; Old, L.J. Cancer/testis antigens, gametogenesis and cancer. Nat. Rev. Cancer 2005, 5, 615-625. [CrossRef]

20. Van der Bruggen, P.; Traversari, C.; Chomez, P.; Lurquin, C.; De Plaen, E.; Van den Eynde, B.; Knuth, A.; Boon, T. A gene encoding an antigen recognized by cytolytic T lymphocytes on a human melanoma. Science 1991, 254, 1643-1647. [CrossRef]

21. Thomas, R.; Al-Khadairi, G.; Roelands, J.; Hendrickx, W.; Dermime, S.; Bedognetti, D.; Decock, J. NY-ESO-1 Based Immunotherapy of Cancer: Current Perspectives. Front. Immunol. 2018, 9, 947. [CrossRef]

22. D'Angelo, S.P.; Melchiori, L.; Merchant, M.S.; Bernstein, D.; Glod, J.; Kaplan, R.; Grupp, S.; Tap, W.D.; Chagin, K.; Binder, G.K.; et al. Antitumor Activity Associated with Prolonged Persistence of Adoptively Transferred NY-ESO-1 (c259)T Cells in Synovial Sarcoma. Cancer Discov. 2018, 8, 944-957. [CrossRef]

23. Almeida, L.G.; Sakabe, N.J.; deOliveira, A.R.; Silva, M.C.; Mundstein, A.S.; Cohen, T.; Chen, Y.T.; Chua, R.; Gurung, S.; Gnjatic, S.; et al. CTdatabase: A knowledge-base of high-throughput and curated data on cancer-testis antigens. Nucleic Acids Res. 2009, 37, D816-D819. [CrossRef]

24. Wang, C.; Gu, Y.; Zhang, K.; Xie, K.; Zhu, M.; Dai, N.; Jiang, Y.; Guo, X.; Liu, M.; Dai, J.; et al. Systematic identification of genes with a cancer-testis expression pattern in 19 cancer types. Nat. Commun. 2016, 7, 10499. [CrossRef]

25. Da Silva, V.L.; Fonseca, A.F.; Fonseca, M.; da Silva, T.E.; Coelho, A.C.; Kroll, J.E.; de Souza, J.E.S.; Stransky, B.; de Souza, G.A.; de Souza, S.J. Genome-wide identification of cancer/testis genes and their association with prognosis in a pan-cancer analysis. Oncotarget 2017, 8, 92966-92977. [CrossRef]

26. Rousseaux, S.; Debernardi, A.; Jacquiau, B.; Vitte, A.L.; Vesin, A.; Nagy-Mignotte, H.; Moro-Sibilot, D.; Brichon, P.Y.; Lantuejoul, S.; Hainaut, P.; et al. Ectopic activation of germline and placental genes identifies aggressive metastasis-prone lung cancers. Sci. Transl. Med. 2013, 5, 186ra66. [CrossRef]

27. Maxfield, K.E.; Taus, P.J.; Corcoran, K.; Wooten, J.; Macion, J.; Zhou, Y.; Borromeo, M.; Kollipara, R.K.; Yan, J.; Xie, Y.; et al. Comprehensive functional characterization of cancer-testis antigens defines obligate participation in multiple hallmarks of cancer. Nat. Commun. 2015, 6, 8840. [CrossRef]

28. Pineda, C.T.; Ramanathan, S.; Fon Tacer, K.; Weon, J.L.; Potts, M.B.; Ou, Y.H.; White, M.A.; Potts, P.R. Degradation of AMPK by a cancer-specific ubiquitin ligase. Cell 2015, 160, 715-728. [CrossRef]

29. Gibbs, Z.A.; Whitehurst, A.W. Emerging Contributions of Cancer/Testis Antigens to Neoplastic Behaviors. Trends Cancer 2018, 4 , 701-712. [CrossRef]

30. Esmaeili, R.; Majidzadeh, A.K.; Farahmand, L.; Ghasemi, M.; Salehi, M.; Khoshdel, A.R. AKAP3 correlates with triple negative status and disease free survival in breast cancer. BMC Cancer 2015, 15, 681. [CrossRef]

31. Sharma, S.; Qian, F.; Keitz, B.; Driscoll, D.; Scanlan, M.J.; Skipper, J.; Rodabaugh, K.; Lele, S.; Old, L.J.; Odunsi, K. A-kinase anchoring protein 3 messenger RNA expression correlates with poor prognosis in epithelial ovarian cancer. Gynecol. Oncol. 2005, 99, 183-188. [CrossRef]

32. Hamai, A.; Memeo, L.; Colarossi, C.; Canzonieri, V.; Perin, T.; Ayyoub, M.; Valmori, D. Expression of MAGE-A antigens is frequent in triple-negative breast cancers but does not correlate with that of basal-like markers. Ann. Oncol. 2011, 22, 986-987. [CrossRef]

33. Curigliano, G.; Viale, G.; Ghioni, M.; Jungbluth, A.A.; Bagnardi, V.; Spagnoli, G.C.; Neville, A.M.; Nole, F.; Rotmensz, N.; Goldhirsch, A. Cancer-testis antigen expression in triple-negative breast cancer. Ann. Oncol. 2011, 22, 98-103. [CrossRef]

34. Grigoriadis, A.; Caballero, O.L.; Hoek, K.S.; da Silva, L.; Chen, Y.T.; Shin, S.J.; Jungbluth, A.A.; Miller, L.D.; Clouston, D.; Cebon, J.; et al. CT-X antigen expression in human breast cancer. Proc. Natl. Acad. Sci. USA 2009, 106, 13493-13498. [CrossRef] [PubMed]

35. Chen, Y.T.; Ross, D.S.; Chiu, R.; Zhou, X.K.; Chen, Y.Y.; Lee, P.; Hoda, S.A.; Simpson, A.J.; Old, L.J.; Caballero, O.; et al. Multiple cancer/testis antigens are preferentially expressed in hormone-receptor negative and high-grade breast cancers. PLoS ONE 2011, 6, e17876. [CrossRef]

36. Karn, T.; Pusztai, L.; Ruckhaberle, E.; Liedtke, C.; Muller, V.; Schmidt, M.; Metzler, D.; Wang, J.; Coombes, K.R.; Gatje, R.; et al. Melanoma antigen family A identified by the bimodality index defines a subset of triple negative breast cancers as candidates for immune response augmentation. Eur. J. Cancer 2012, 48, 12-23. [CrossRef] [PubMed]

37. Ayyoub, M.; Scarlata, C.M.; Hamai, A.; Pignon, P.; Valmori, D. Expression of MAGE-A3/6 in primary breast cancer is associated with hormone receptor negative status, high histologic grade, and poor survival. J. Immunother. 2014, 37, 73-76. [CrossRef]

38. Yang, F.; Zhou, X.; Miao, X.; Zhang, T.; Hang, X.; Tie, R.; Liu, N.; Tian, F.; Wang, F.; Yuan, J. MAGEC2, an epithelial-mesenchymal transition inducer, is associated with breast cancer metastasis. Breast Cancer Res. Treat. 2014, 145, 23-32. [CrossRef]

39. Badovinac Crnjevic, T.; Spagnoli, G.; Juretic, A.; Jakic-Razumovic, J.; Podolski, P.; Saric, N. High expression of MAGE-A10 cancer-testis antigen in triple-negative breast cancer. Med. Oncol. 2012, 29, 1586-1591. [CrossRef]

40. Raghavendra, A.; Kalita-de Croft, P.; Vargas, A.C.; Smart, C.E.; Simpson, P.T.; Saunus, J.M.; Lakhani, S.R. Expression of MAGE-A and NY-ESO-1 cancer/testis antigens is enriched in triple-negative invasive breast cancers. Histopathology 2018, 73, 68-80. [CrossRef]

41. Zhao, Q.; Xu, W.T.; Shalieer, T. Pilot Study on MAGE-C2 as a Potential Biomarker for Triple-Negative Breast Cancer. Dis. Markers 2016, 2016, 2325987. [CrossRef]

42. Wang, H.; Sang, M.; Geng, C.; Liu, F.; Gu, L.; Shan, B. MAGE-A is frequently expressed in triple negative breast cancer and associated with epithelial-mesenchymal transition. Neoplasma 2016, 63, 44-56. [CrossRef] 
43. Tessari, A.; Pilla, L.; Silvia, D.; Duca, M.; Paolini, B.; Carcangiu, M.L.; Mariani, L.; de Braud, F.G.; Cresta, S. Expression of NY-ESO-1, MAGE-A3, PRAME and WT1 in different subgroups of breast cancer: An indication to immunotherapy? Breast 2018, 42, 68-73. [CrossRef]

44. Mrklic, I.; Spagnoli, G.C.; Juretic, A.; Pogorelic, Z.; Tomic, S. Co-expression of cancer testis antigens and topoisomerase 2-alpha in triple negative breast carcinomas. Acta Histochem. 2014, 116, 740-746. [CrossRef]

45. Cabezon, T.; Gromova, I.; Gromov, P.; Serizawa, R.; Timmermans Wielenga, V.; Kroman, N.; Celis, J.E.; Moreira, J.M. Proteomic profiling of triple-negative breast carcinomas in combination with a three-tier orthogonal technology approach identifies Mage-A4 as potential therapeutic target in estrogen receptor negative breast cancer. Mol. Cell. Proteom. 2013, 12, 381-394. [CrossRef] [PubMed]

46. Tchou, J.; Wang, L.C.; Selven, B.; Zhang, H.; Conejo-Garcia, J.; Borghaei, H.; Kalos, M.; Vondeheide, R.H.; Albelda, S.M.; June, C.H.; et al. Mesothelin, a novel immunotherapy target for triple negative breast cancer. Breast Cancer Res. Treat. 2012, 133, 799-804. [CrossRef]

47. Tozbikian, G.; Brogi, E.; Kadota, K.; Catalano, J.; Akram, M.; Patil, S.; Ho, A.Y.; Reis-Filho, J.S.; Weigelt, B.; Norton, L.; et al. Mesothelin expression in triple negative breast carcinomas correlates significantly with basal-like phenotype, distant metastases and decreased survival. PLoS ONE 2014, 9, e114900. [CrossRef]

48. Parinyanitikul, N.; Blumenschein, G.R.; Wu, Y.; Lei, X.; Chavez-Macgregor, M.; Smart, M.; Gonzalez-Angulo, A.M. Mesothelin expression and survival outcomes in triple receptor negative breast cancer. Clin. Breast Cancer 2013, 13, 378-384. [CrossRef]

49. Link, T.; Kuithan, F.; Ehninger, A.; Kuhlmann, J.D.; Kramer, M.; Werner, A.; Gatzweiler, A.; Richter, B.; Ehninger, G.; Baretton, G.; et al. Exploratory investigation of PSCA-protein expression in primary breast cancer patients reveals a link to HER2/neu overexpression. Oncotarget 2017, 8, 54592-54603. [CrossRef]

50. Meng, F.; Liu, B.; Xie, G.; Song, Y.; Zheng, X.; Qian, X.; Li, S.; Jia, H.; Zhang, X.; Zhang, L.; et al. Amplification and overexpression of PSCA at 8q24 in invasive micropapillary carcinoma of breast. Breast Cancer Res. Treat. 2017, 166, 383-392. [CrossRef] [PubMed]

51. Henry, C.; Quadir, A.; Hawkins, N.J.; Jary, E.; Llamosas, E.; Kumar, D.; Daniels, B.; Ward, R.L.; Ford, C.E. Expression of the novel Wnt receptor ROR2 is increased in breast cancer and may regulate both beta-catenin dependent and independent Wnt signalling. J. Cancer Res. Clin. Oncol. 2015, 141, 243-254. [CrossRef]

52. Kannan, A.; Philley, J.V.; Hertweck, K.L.; Ndetan, H.; Singh, K.P.; Sivakumar, S.; Wells, R.B.; Vadlamudi, R.K.; Dasgupta, S. Cancer Testis Antigen Promotes Triple Negative Breast Cancer Metastasis and is Traceable in the Circulating Extracellular Vesicles. Sci. Rep. 2019, 9, 11632. [CrossRef]

53. Maine, E.A.; Westcott, J.M.; Prechtl, A.M.; Dang, T.T.; Whitehurst, A.W.; Pearson, G.W. The cancer-testis antigens SPANX-A/C/D and CTAG2 promote breast cancer invasion. Oncotarget 2016, 7, 14708-14726. [CrossRef]

54. Ademuyiwa, F.O.; Bshara, W.; Attwood, K.; Morrison, C.; Edge, S.B.; Karpf, A.R.; James, S.A.; Ambrosone, C.B.; O'Connor, T.L.; Levine, E.G.; et al. NY-ESO-1 cancer testis antigen demonstrates high immunogenicity in triple negative breast cancer. PLoS ONE 2012, 7, e38783. [CrossRef]

55. Bandic, D.; Juretic, A.; Sarcevic, B.; Separovic, V.; Kujundzic-Tiljak, M.; Hudolin, T.; Spagnoli, G.C.; Covic, D.; Samija, M. Expression and possible prognostic role of MAGE-A4, NY-ESO-1, and HER-2 antigens in women with relapsing invasive ductal breast cancer: Retrospective immunohistochemical study. Croat. Med. J. 2006, 47, 32-41.

56. Lee, H.J.; Kim, J.Y.; Song, I.H.; Park, I.A.; Yu, J.H.; Gong, G. Expression of NY-ESO-1 in Triple-Negative Breast Cancer Is Associated with Tumor-Infiltrating Lymphocytes and a Good Prognosis. Oncology 2015, 89, 337-344. [CrossRef] [PubMed]

57. Curigliano, G.; Bagnardi, V.; Ghioni, M.; Louahed, J.; Brichard, V.; Lehmann, F.F.; Marra, A.; Trapani, D.; Criscitiello, C.; Viale, G. Expression of tumor-associated antigens in breast cancer subtypes. Breast 2020, 49, 202-209. [CrossRef]

58. Epping, M.T.; Hart, A.A.; Glas, A.M.; Krijgsman, O.; Bernards, R. PRAME expression and clinical outcome of breast cancer. Br. J. Cancer 2008, 99, 398-403. [CrossRef]

59. Yao, J.; Caballero, O.L.; Yung, W.K.; Weinstein, J.N.; Riggins, G.J.; Strausberg, R.L.; Zhao, Q. Tumor subtype-specific cancer-testis antigens as potential biomarkers and immunotherapeutic targets for cancers. Cancer Immunol. Res. 2014, 2, 371-379. [CrossRef]

60. Al-Khadairi, G.; Naik, A.; Thomas, R.; Al-Sulaiti, B.; Rizly, S.; Decock, J. PRAME promotes epithelial-to-mesenchymal transition in triple negative breast cancer. J. Transl. Med. 2019, 17, 9. [CrossRef]

61. Kanojia, D.; Garg, M.; Gupta, S.; Gupta, A.; Suri, A. Sperm-associated antigen 9, a novel biomarker for early detection of breast cancer. Cancer Epidemiol. Biomark. Prev. 2009, 18, 630-639. [CrossRef]

62. Sinha, A.; Agarwal, S.; Parashar, D.; Verma, A.; Saini, S.; Jagadish, N.; Ansari, A.S.; Lohiya, N.K.; Suri, A. Down regulation of SPAG9 reduces growth and invasive potential of triple-negative breast cancer cells: Possible implications in targeted therapy. J. Exp. Clin. Cancer Res. 2013, 32, 69. [CrossRef]

63. Song, Z.B.; Ni, J.S.; Wu, P.; Bao, Y.L.; Liu, T.; Li, M.; Fan, C.; Zhang, W.J.; Sun, L.G.; Huang, Y.X.; et al. Testes-specific protease 50 promotes cell invasion and metastasis by increasing NF-kappaB-dependent matrix metalloproteinase-9 expression. Cell Death Dis. 2015, 6, e1703. [CrossRef]

64. Wang, M.; Bao, Y.L.; Wu, Y.; Yu, C.L.; Meng, X.Y.; Huang, Y.X.; Sun, Y.; Zheng, L.H.; Li, Y.X. Basic FGF downregulates TSP50 expression via the ERK/Sp1 pathway. J. Cell. Biochem. 2010, 111, 75-81. [CrossRef]

65. Gibbs, Z.A.; Reza, L.C.; Cheng, C.C.; Westcott, J.M.; McGlynn, K.; Whitehurst, A.W. The testis protein ZNF165 is a SMAD3 cofactor that coordinates oncogenic TGFbeta signaling in triple-negative breast cancer. eLife 2020, 9. [CrossRef] 
66. Kaufmann, J.; Wentzensen, N.; Brinker, T.J.; Grabe, N. Large-scale in-silico identification of a tumor-specific antigen pool for targeted immunotherapy in triple-negative breast cancer. Oncotarget 2019, 10, 2515-2529. [CrossRef]

67. Paret, C.; Simon, P.; Vormbrock, K.; Bender, C.; Kolsch, A.; Breitkreuz, A.; Yildiz, O.; Omokoko, T.; Hubich-Rau, S.; Hartmann, C.; et al. CXorf61 is a target for T cell based immunotherapy of triple-negative breast cancer. Oncotarget 2015, 6, 25356-25367. [CrossRef]

68. Kondo, Y.; Fukuyama, T.; Yamamura, R.; Futawatari, N.; Ichiki, Y.; Tanaka, Y.; Nishi, Y.; Takahashi, Y.; Yamazaki, H.; Kobayashi, N.; et al. Detection of KK-LC-1 Protein, a Cancer/Testis Antigen, in Patients with Breast Cancer. Anticancer. Res. 2018, 38, 5923-5928. [CrossRef]

69. Mirandola, L.; Pedretti, E.; Figueroa, J.A.; Chiaramonte, R.; Colombo, M.; Chapman, C.; Grizzi, F.; Patrinicola, F.; Kast, W.M.; Nguyen, D.D.; et al. Cancer testis antigen Sperm Protein 17 as a new target for triple negative breast cancer immunotherapy. Oncotarget 2017, 8, 74378-74390. [CrossRef]

70. Newman, J.A.; Cooper, C.D.; Roos, A.K.; Aitkenhead, H.; Oppermann, U.C.; Cho, H.J.; Osman, R.; Gileadi, O. Structures of Two Melanoma-Associated Antigens Suggest Allosteric Regulation of Effector Binding. PLoS ONE 2016, 11, e0148762. [CrossRef]

71. Poojary, M.; Jishnu, P.V.; Kabekkodu, S.P. Prognostic Value of Melanoma-Associated Antigen-A (MAGE-A) Gene Expression in Various Human Cancers: A Systematic Review and Meta-analysis of 7428 Patients and 44 Studies. Mol. Diagn. Ther. 2020. [CrossRef]

72. Weon, J.L.; Potts, P.R. The MAGE protein family and cancer. Curr. Opin. Cell Biol. 2015, 37, 1-8. [CrossRef]

73. Zajac, P.; Schultz-Thater, E.; Tornillo, L.; Sadowski, C.; Trella, E.; Mengus, C.; Iezzi, G.; Spagnoli, G.C. MAGE-A Antigens and Cancer Immunotherapy. Front. Med. (Lausanne) 2017, 4, 18. [CrossRef] [PubMed]

74. Lv, J.; Li, P. Mesothelin as a biomarker for targeted therapy. Biomark. Res. 2019, 7, 18. [CrossRef]

75. Morello, A.; Sadelain, M.; Adusumilli, P.S. Mesothelin-Targeted CARs: Driving T Cells to Solid Tumors. Cancer Discov. 2016, 6, 133-146. [CrossRef]

76. Masiakowski, P.; Carroll, R.D. A novel family of cell surface receptors with tyrosine kinase-like domain. J. Biol. Chem. 1992, 267, 26181-26190. [CrossRef]

77. Westbrook, V.A.; Diekman, A.B.; Klotz, K.L.; Khole, V.V.; von Kap-Herr, C.; Golden, W.L.; Eddy, R.L.; Shows, T.B.; Stoler, M.H.; Lee, C.Y.; et al. Spermatid-specific expression of the novel X-linked gene product SPAN-X localized to the nucleus of human spermatozoa. Biol. Reprod. 2000, 63, 469-481. [CrossRef]

78. Carnegie, G.K.; Means, C.K.; Scott, J.D. A-kinase anchoring proteins: From protein complexes to physiology and disease. IUBMB Life 2009, 61, 394-406. [CrossRef]

79. Sugita, Y.; Wada, H.; Fujita, S.; Nakata, T.; Sato, S.; Noguchi, Y.; Jungbluth, A.A.; Yamaguchi, M.; Chen, Y.T.; Stockert, E.; et al. NY-ESO-1 expression and immunogenicity in malignant and benign breast tumors. Cancer Res. 2004, 64, 2199-2204. [CrossRef]

80. Gjerstorff, M.F.; Andersen, M.H.; Ditzel, H.J. Oncogenic cancer/testis antigens: Prime candidates for immunotherapy. Oncotarget 2015, 6, 15772-15787. [CrossRef]

81. Doyle, J.M.; Gao, J.; Wang, J.; Yang, M.; Potts, P.R. MAGE-RING protein complexes comprise a family of E3 ubiquitin ligases. Mol. Cell 2010, 39, 963-974. [CrossRef]

82. Xu, Y.; Zou, R.; Wang, J.; Wang, Z.W.; Zhu, X. The role of the cancer testis antigen PRAME in tumorigenesis and immunotherapy in human cancer. Cell Prolif. 2020, 53, e12770. [CrossRef]

83. Fukami, M.; Wada, Y.; Miyabayashi, K.; Nishino, I.; Hasegawa, T.; Nordenskjold, A.; Camerino, G.; Kretz, C.; Buj-Bello, A.; Laporte, J.; et al. CXorf6 is a causative gene for hypospadias. Nat. Genet. 2006, 38, 1369-1371. [CrossRef]

84. Ogata, T.; Laporte, J.; Fukami, M. MAMLD1 (CXorf6): A new gene involved in hypospadias. Horm. Res. 2009, 71, $245-252$. [CrossRef]

85. Grizzi, F.; Gaetani, P.; Franceschini, B.; Di Ieva, A.; Colombo, P.; Ceva-Grimaldi, G.; Bollati, A.; Frezza, E.E.; Cobos, E.; Rodriguez y Baena, R.; et al. Sperm protein 17 is expressed in human nervous system tumours. BMC Cancer 2006, 6, 23. [CrossRef]

86. Gupta, G.; Sharma, R.; Chattopadhyay, T.K.; Gupta, S.D.; Ralhan, R. Clinical significance of sperm protein 17 expression and immunogenicity in esophageal cancer. Int. J. Cancer 2007, 120, 1739-1747. [CrossRef]

87. Lim, S.H.; Wang, Z.; Chiriva-Internati, M.; Xue, Y. Sperm protein 17 is a novel cancer-testis antigen in multiple myeloma. Blood 2001, 97, 1508-1510. [CrossRef] [PubMed]

88. Nakazato, T.; Kanuma, T.; Tamura, T.; Faried, L.S.; Aoki, H.; Minegishi, T. Sperm protein 17 influences the tissue-specific malignancy of clear cell adenocarcinoma in human epithelial ovarian cancer. Int. J. Gynecol. Cancer 2007, 17, 426-432. [CrossRef]

89. Bumm, K.; Grizzi, F.; Franceschini, B.; Koch, M.; Iro, H.; Wurm, J.; Ceva-Grimaldi, G.; Dimmler, A.; Cobos, E.; Dioguardi, N.; et al. Sperm protein 17 expression defines 2 subsets of primary esthesioneuroblastoma. Hum. Pathol. 2005, 36, 1289-1293. [CrossRef]

90. Chiriva-Internati, M. Sperm protein 17: Clinical relevance of a cancer/testis antigen, from contraception to cancer immunotherapy, and beyond. Int. Rev. Immunol. 2011, 30, 138-149. [CrossRef]

91. Lacy, H.M.; Sanderson, R.D. Sperm protein 17 is expressed on normal and malignant lymphocytes and promotes heparan sulfate-mediated cell-cell adhesion. Blood 2001, 98, 2160-2165. [CrossRef]

92. Li, F.Q.; Han, Y.L.; Liu, Q.; Wu, B.; Huang, W.B.; Zeng, S.Y. Overexpression of human sperm protein 17 increases migration and decreases the chemosensitivity of human epithelial ovarian cancer cells. BMC Cancer 2009, 9, 323. [CrossRef] 
93. Call, K.M.; Glaser, T.; Ito, C.Y.; Buckler, A.J.; Pelletier, J.; Haber, D.A.; Rose, E.A.; Kral, A.; Yeger, H.; Lewis, W.H.; et al. Isolation and characterization of a zinc finger polypeptide gene at the human chromosome 11 Wilms' tumor locus. Cell 1990, 60, 509-520. [CrossRef]

94. Tien, T.Z.; Lee, J.; Lim, J.C.T.; Chen, X.Y.; Thike, A.A.; Tan, P.H.; Yeong, J.P.S. Delineating the breast cancer immune microenvironment in the era of multiplex immunohistochemistry/immunofluorescence. Histopathology 2021, 79, 139-159. [CrossRef]

95. Tan, W.C.C.; Nerurkar, S.N.; Cai, H.Y.; Ng, H.H.M.; Wu, D.; Wee, Y.T.F.; Lim, J.C.T.; Yeong, J.; Lim, T.K.H. Overview of multiplex immunohistochemistry/immunofluorescence techniques in the era of cancer immunotherapy. Cancer Commun. (Lond.) 2020, 40, 135-153. [CrossRef]

96. Dixon, A.R.; Bathany, C.; Tsuei, M.; White, J.; Barald, K.F.; Takayama, S. Recent developments in multiplexing techniques for immunohistochemistry. Expert Rev. Mol. Diagn. 2015, 15, 1171-1186. [CrossRef]

97. Lu, S.; Stein, J.E.; Rimm, D.L.; Wang, D.W.; Bell, J.M.; Johnson, D.B.; Sosman, J.A.; Schalper, K.A.; Anders, R.A.; Wang, H.; et al. Comparison of Biomarker Modalities for Predicting Response to PD-1/PD-L1 Checkpoint Blockade: A Systematic Review and Meta-analysis. JAMA Oncol. 2019, 5, 1195-1204. [CrossRef]

98. Yeong, J.; Tan, T.; Chow, Z.L.; Cheng, Q.; Lee, B.; Seet, A.; Lim, J.X.; Lim, J.C.T.; Ong, C.C.H.; Thike, A.A.; et al. Multiplex immunohistochemistry/immunofluorescence (mIHC/IF) for PD-L1 testing in triple-negative breast cancer: A translational assay compared with conventional IHC. J. Clin. Pathol. 2020, 73, 557-562. [CrossRef]

99. Taube, J.M.; Roman, K.; Engle, E.L.; Wang, C.; Ballesteros-Merino, C.; Jensen, S.M.; McGuire, J.; Jiang, M.; Coltharp, C.; Remeniuk, B.; et al. Multi-institutional TSA-amplified Multiplexed Immunofluorescence Reproducibility Evaluation (MITRE) Study. J. Immunother. Cancer 2021, 9. [CrossRef]

100. Cho, C.H.; Cho, M.; Park, J.K. Biomarker barcodes: Multiplexed microfluidic immunohistochemistry enables high-throughput analysis of tissue microarray. Lab Chip 2021. [CrossRef]

101. Marotti, J.D.; de Abreu, F.B.; Wells, W.A.; Tsongalis, G.J. Triple-Negative Breast Cancer: Next-Generation Sequencing for Target Identification. Am. J. Pathol. 2017, 187, 2133-2138. [CrossRef]

102. Dillon, J.L.; Mockus, S.M.; Ananda, G.; Spotlow, V.; Wells, W.A.; Tsongalis, G.J.; Marotti, J.D. Somatic gene mutation analysis of triple negative breast cancers. Breast 2016, 29, 202-207. [CrossRef]

103. Staaf, J.; Glodzik, D.; Bosch, A.; Vallon-Christersson, J.; Reutersward, C.; Hakkinen, J.; Degasperi, A.; Amarante, T.D.; Saal, L.H.; Hegardt, C.; et al. Whole-genome sequencing of triple-negative breast cancers in a population-based clinical study. Nat. Med. 2019, 25, 1526-1533. [CrossRef]

104. Pinto, C.; Biffoni, M.; Popoli, P.; Marchetti, A.; Marchetti, P.; Martini, N.; Normanno, N. Molecular Tests and Target Therapies in Oncology: Recommendations from the Italian workshop. Future Oncol. 2021. [CrossRef]

105. Li, X.F.; Ren, P.; Shen, W.Z.; Jin, X.; Zhang, J. The expression, modulation and use of cancer-testis antigens as potential biomarkers for cancer immunotherapy. Am. J. Transl. Res. 2020, 12, 7002-7019.

106. Somaiah, N.; Block, M.S.; Kim, J.W.; Shapiro, G.I.; Do, K.T.; Hwu, P.; Eder, J.P.; Jones, R.L.; Lu, H.; Ter Meulen, J.H.; et al First-in-Class, First-in-Human Study Evaluating LV305, a Dendritic-Cell Tropic Lentiviral Vector, in Sarcoma and Other Solid Tumors Expressing NY-ESO-1. Clin. Cancer Res. 2019, 25, 5808-5817. [CrossRef]

107. Mahipal, A.; Ejadi, S.; Gnjatic, S.; Kim-Schulze, S.; Lu, H.; Ter Meulen, J.H.; Kenney, R.; Odunsi, K. First-in-human phase 1 dose-escalating trial of G305 in patients with advanced solid tumors expressing NY-ESO-1. Cancer Immunol. Immunother. 2019, 68, 1211-1222. [CrossRef]

108. Pollack, S.M. The potential of the CMB305 vaccine regimen to target NY-ESO-1 and improve outcomes for synovial sarcoma and myxoid/round cell liposarcoma patients. Expert Rev. Vaccines 2018, 17, 107-114. [CrossRef]

109. Baumgaertner, P.; Costa Nunes, C.; Cachot, A.; Maby-El Hajjami, H.; Cagnon, L.; Braun, M.; Derre, L.; Rivals, J.P.; Rimoldi, D.; Gnjatic, S.; et al. Vaccination of stage III/IV melanoma patients with long NY-ESO-1 peptide and CpG-B elicits robust CD8(+) and CD4(+) T-cell responses with multiple specificities including a novel DR7-restricted epitope. Oncoimmunology 2016, 5, e1216290. [CrossRef]

110. Lu, Y.C.; Parker, L.L.; Lu, T.; Zheng, Z.; Toomey, M.A.; White, D.E.; Yao, X.; Li, Y.F.; Robbins, P.F.; Feldman, S.A.; et al. Treatment of Patients with Metastatic Cancer Using a Major Histocompatibility Complex Class II-Restricted T-Cell Receptor Targeting the Cancer Germline Antigen MAGE-A3. J. Clin. Oncol. 2017, 35, 3322-3329. [CrossRef]

111. Hong, D.S.; Tine, B.A.V.; Olszanski, A.J.; Johnson, M.L.; Liebner, D.A.; Trivedi, T.; Lin, Q.; Elefant, E.; Dryer-Minnerly, R.; Navenot, J.-M.; et al. Phase I dose escalation and expansion trial to assess the safety and efficacy of ADP-A2M4 SPEAR T cells in advanced solid tumors. J. Clin. Oncol. 2020, 38, 102. [CrossRef]

112. Jin, S.; Cao, S.; Li, J.; Meng, Q.; Wang, C.; Yao, L.; Lang, Y.; Cao, J.; Shen, J.; Pan, B.; et al. Cancer/testis antigens (CTAs) expression in resected lung cancer. Onco Targets Ther. 2018, 11, 4491-4499. [CrossRef] 